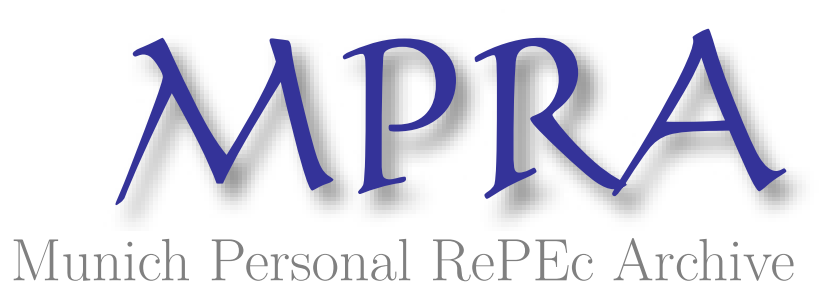

\title{
Airline Strategies: An Empirical Analysis of Profitability and Market Share
}

Lawrence, Craig

University of New South Wales

November 1993

Online at https://mpra.ub.uni-muenchen.de/11914/

MPRA Paper No. 11914, posted 04 Dec 2008 04:02 UTC 


\section{Airline Strategies: An Empirical Analysis of Profitability and Market Share}

A Minor Thesis in the Department of Economics and Management, University College, University of New South Wales, Australian Defence Force Academy, presented as part of assessment for a Master of Management Economics.

Craig Lawrence

November 1993 


\section{Table of Contents}

Foreword iv

Abstract $\quad \mathrm{V}$

Chapter 1 Introduction 1

Chapter 2 A Strategic Framework 3

Organisational Goals 3

Business Strategy and the Situation Assessment $\quad 5$

Marketing 9

Chapter 3 Theories for Airline Management 12

Strategic Market Planning $\quad 12$

Airline Management Strategies $\quad 15$

Developing a Positional Advantage $\quad 19$

Chapter 4 Elements of Market Share and Profitability 25

Market Share $\quad 25$

Enhancing Profitability 28

Value Chains 30

Profit Impact of Marketing Strategies $\quad 34$ 
Chapter 5 An Empirical Analysis of Market Share and Profitability

A Demand Model for Air Services on A Route

Counterfactual Analysis - Conditions Establishing A Relationship Between Profit and Market Share

Price and Frequency Connection Between Profitability and Market Share

Defining a Cost Function for Air Services 48

Competition in the Model 49

A Simple Network Model of Trip Generation 53

Chapter 6 Conclusions

Bibliography

\section{Exhibits}

2.1 Elements of a Situation Assessment 7

2.2 An Hierarchical Analysis of Market Segmentation 9

3.1 Directions for Expanding the Business Direction 16

3.2 Positional Advantage 19

3.3 Elements of a Market Strategy 24

4.1 Components of Profitability 28

4.2 Sources of Profitability 30

4.3 Enhancing Customer Value 31

4.4 Alternative Value Chains in Airlines 33

4.6 Avenue for Attacking Leaders 34

4.7 The Business Portfolio Matrix 35

5.1 Comparison of Actual and Estimated Passenger Numbers 40

5.2 Assessment of Changes in Service Quality 46

5.3 Market Share - Relative Air Fare and Frequency
Impacts

5.4 The Price-Frequency Market Share Surface 48

5.5 Frequency-Fare Combinations of Market Share 51

5.6 Hypothetical Route Network 54

5.7 Gravity Model Passenger Generation 54

5.8 Route Network: South-east Australia 55

5.9 Network Traffic in the Model 56 


\section{Foreword}

The airline industry is one of the world's global dynamic industries. It is an exciting, glamorous, tumultuous industry at the leading edge of high technology and customer service. It is this interface between high technology passenger transportation and superior customer service that interests a large number of business people, scholars, bureaucrats, politicians and travellers.

My experience as a researcher and as a policy adviser in the Australian context drew me to this analysis as part of the requirements for a Master of Management Economics at he Australian Defence Force Academy. During the course of writing this thesis I have explored the relationship between strategic management theory and airline performance.

I am indebted to my thesis supervisor, Dr Gary Manger, for his advice and guidance in preparing this paper. I would also like to acknowledge the support of the Commonwealth Department of Tourism in writing this paper.

Any imperfections remain my own.

Craig Lawrence

November 1993 


\section{Abstract}

This paper examines the relationship between airline profitability and market share in the context of contemporary strategic business theory.

The paper provides a general overview of the business environment in which airlines operate, provides some of the organisational goals airlines pursue, and develops a situation assessment template for the airline industry. Theories of business management are then evaluated with respect to the nature of the airline industry before the major elements of market share and profitability are examined.

An empirical analysis based on a model of a domestic Australian route is used to draw some conclusions about the impact of different business strategies on airline profitability and market share. This is then broadened through the introduction of a simple network model to examine the potential impact of operating a network of services.

The paper reaches the conclusion that the simplistic profitability-market share relationship is not applicable to the airline industry, given that there are a large number of other factors impacting on airline performance. 


\section{Chapter 1 Introduction}

Aviation is a major global industry accounting for more than 21 million jobs and generating $\$ 700$ billion in gross annual output. ${ }^{1}$ It is a capital intensive industry requiring substantial investments by firms and governments in aircraft, airport terminals and ancillary equipment. The aviation industry is one of several industries at the centre of the travel and tourism sector of world commerce. A key insight into this crucial industry can be developed by understanding how the competitive pressures in the airline industry affect the way domestic and international carriers operate. This minor thesis examines strategies pursued by airlines in order to maximise market share and profit, which is a core element of understanding how and why airlines conduct their business.

The minor thesis rests on a framework of four key chapters which form integrated components of the analysis.

Chapter 2 provides a review of airline goals, business strategy and the role of marketing. Particular focus is placed on the marketing concepts of product, price, placement and promotion and marketing decision-making processes including a situation assessment.

Chapter 3 examines generic management strategies in the context of the aviation industry, identifying the key factors influencing market share and airline profitability.

1 Air Transport Action Group (1991), p4. The aviation industry is a global growth industry, passengers and freight are expected to increase at an average annual rate of 5 per cent thorough the 1990 s and by the year 2010 aviation's economic impact could exceed US $\$ 1.5$ trillion with over 30 million jobs provided. The Asia-Pacific region's share of worldwide scheduled passenger traffic is expected to grow from 25 per cent in 1985 to 51 per cent in 2010, with Japan remaining the dominant traffic market (International Air Transport Association (1992), p3) 
Chapter 4 discusses the elements of market share and profitability, introducing a discussion of Porter's value chain in relation to airline strategy.

Chapter 5 provides an empirical study of the nature of the profit-market share nexus, developing a demand model and an elementary network model to assess the implications for airline management of pursuing the strategies mentioned above.

Chapter 6 draws these threads together in a series of interrelated conclusions about the nature of the airline industry in Australia and overseas and the consequences of pursuing market share or market leadership at the expense of profitability. 


\section{Chapter 2 A Organisational Framework}

This chapter addresses the significance of organisational goals, situation assessments and marketing in the context of the airline industry. These issues set the background for an analysis of the industry based on contemporary management theories. A situation assessment is used to explore the range of factors which airline managements have to consider. Marketing is another important element of the organisational framework which affects the performance of an airline and several marketing concepts are briefly discussed to highlight the differences be trween airline services and traditional goods.

\section{Organisational Goals}

The key goals pursued by airlines are critical to airline performance, affecting the quality of service provided and the profitability of carriers. Airline goals critically shape the strategic path an airline will take. There are five major goals which organisations pursue. ${ }^{2}$ These are production, inventory, sales, market share and profit goals. Other analyses examine organisational goals in terms of social or systems approaches. For this paper we will examine goals which relate directly to the process of producing, selling and providing airline seats. Each one of these goals has implications for the marketing strategy that an airline will pursue.

The production goal relates to fluctuation and level of output. For the airline this involves the selection of aircraft types, numbers, routes and terminal facilities in additional to crucial ancillary services such as reservation and ticketing, baggage handling, and connections with other services such as car rental agencies and

2 Mullins (1989), p89 
hotels. ${ }^{3}$ This production goal has major implications for the capital structure of the company and its orientation in the market. For example, an airline acquiring Boeing 737 aircraft would not be well-placed to compete with better appointed, long-haul competitors operating on the trans-Pacific route because the 737 is not suited to that type of operation. 4

The inventory goal acts as a buffer between the production and sales goal although there is virtually no ex post inventory management in the airline industry. Ex ante inventory management is crucial to the survival of the airlines however as this primarily involves critical yield management techniques which seek to maximise revenue earned from each flight prior to take off. Once an aircraft is committed to a particular service the challenge is to fill the aircraft with as many high paying passengers as possible..$^{5}$ The inventory goal is one area in which the main conditions for the range of fares offered by the carrier are set according to each market.

The sales goal essentially relates to turnover while the market share goal is concerned with sales effectiveness. This has a strong connection with the ex ante management of airline inventories but is more focused on the traditional aspects of marketing such as promotion and advertising. Airlines have recognised this in the Australian domestic market because they have acquired major travel agencies.

The market share goal is one measure of the relative performance of an airline against other industry participants. Market share, however, can be bought at a price. Compass Airlines in its first incarnation showed that a new domestic entrant could attract a large share of the market by offering a large number of heavily discounted seats but the price that it paid was to incur a large monthly losses which were not sustainable over a long period of time. ${ }^{6}$

The profit goal is related to monetary profit, or profit share, or return on investment. The extent to which profitability is traded off for market share through

3 A point Nyanthi (1993), p1029, makes is that an airline network can be seen as both an airline's production plan and its product.

$4 \quad$ Boeing Commercial Airplane Group (1993), p3.10

5 Nyanthi (1993), p1029. For most businesses, the objective is to achieve targets of profitability.

$6 \quad$ Street, Smith and Spence (1993), p174, believe that Compass failed partly because it chose to compete head-on with incumbent airlines by offering large expansions in capacity on the major routes and underestimating its relative disadvantage in competing for full fare passengers. 
a particular airline marketing strategy is the focus of this paper. It is a matter of debate whether firms strive for increased profitability to grow and develop or survive in order to grow and develop and generate a profit. ${ }^{7}$ A more reasonable assumption for airlines, particularly given the current economic climate and the degree of international competition, is that survival may be the ultimate objective. ${ }^{8}$ Although the profit motive is a necessary condition for an airline's survival it is not sufficient - many other considerations come into play at a strategic management level. For example, international airlines are often national flag carriers and international prestige often interferes with the profit drive. Also, domestic carriers forgo short-term profits and recognise some social obligations by investing in safety equipment which maintains their credibility with the flying public.

This thesis focuses on the market share and profit goals as the critical factors affecting airline performance. It could be argued that these two goals have primacy becuase of their immediate impact on airline operations. Further analysis of market share and profitability in an operational context is provided in Chapter 4.

\section{Airline Business Strategy and the Situation Assessment}

In the highly competitive airline environment, airline managers need to be continually on alert for changes in the industry. Unlike other, more stable mature industries, the airline industry is in a continual state of innovation and aggressive competition. One of the arrows in the airline manager's armoury is the SWOT (strengths, weaknesses, opportunities and threats) analysis. This situation assessment is a key checklist and guide for collecting the appropriate information upon which airline managers can make decisions regarding the strategic direction of the airline.

The SWOT analysis is particularly useful in formulating a business strategy. It can be embedded in the following steps for developing a strategy: ${ }^{9}$

- $\quad$ Business definition - establishing the initial scope of planning activities

$7 \quad$ Mullins (1989), p94

8 Lawrinsky (1993), p204, notes that since 1990 the US airline industry has, at least in nominal terms, lost more money than it made in all the years since commercial aviation began. Whilst many airlines have a high debt level, major US and international airlines still have a positive equity value. 9 Day (1984), pp48-9 
- Situation assessment - analysis of external and internal factors affecting business performance - essentially the SWOT analysis

- $\quad$ Preliminary performance objectives - based on past performance and initial corporate expectations

- $\quad$ Strategy development - identification and evaluation of strategic options

- Implementation - specific actions plans, function and budgets for program areas including timetables

- $\quad$ Monitoring - of performance compared with strategies and objectives.

SWOT analysis provides a useful framework for evaluating for airline marketing strategies. ${ }^{10}$ Strengths can be positive organisational aspects like Qantas's wide range of overseas offices which provide a direct feed of passengers for Australian Airlines. Organisational deficiencies provide a source of weakness which need to be remedied. For example, for several years Ansett Airlines did not introduce a business class which allowed Australian to take the major share in the lucrative domestic business market. ${ }^{11}$ Airlines seek to build upon opportunities such as exclusive access to international routes or synergies which may be attained, such as savings in human resources through the amalgamation of Qantas and Australian airlines. Threats are externally driven developments which provide a direct challenge to airlines. The possible entry of Air New Zealand onto domestic Australian routes provides one example of a threat facing Qantas and Ansett. ${ }^{12}$

A template for a detailed analysis of the scope of a situation assessment is summarised below in Exhibit 2.1.

\footnotetext{
10 Mullins (1989), pp99-100

11 Stephenson and Fox (1987) found that in 1986, while only 3 per cent of US travellers fell into the frequent flier category (more than 12 trips per year by air), they accounted for 27 per cent of all trips. In addition while 48 per cent of trips were for business purposes, these trips accounted for 68 per cent of airline revenues.

12 Street, Smith and Spence (1993), p178, believe that Air New Zealand would be in the best position to contest the domestic market should the efficiency of Ansett Australia and Australian Airlines decline to such an extent to invite entry.
} 


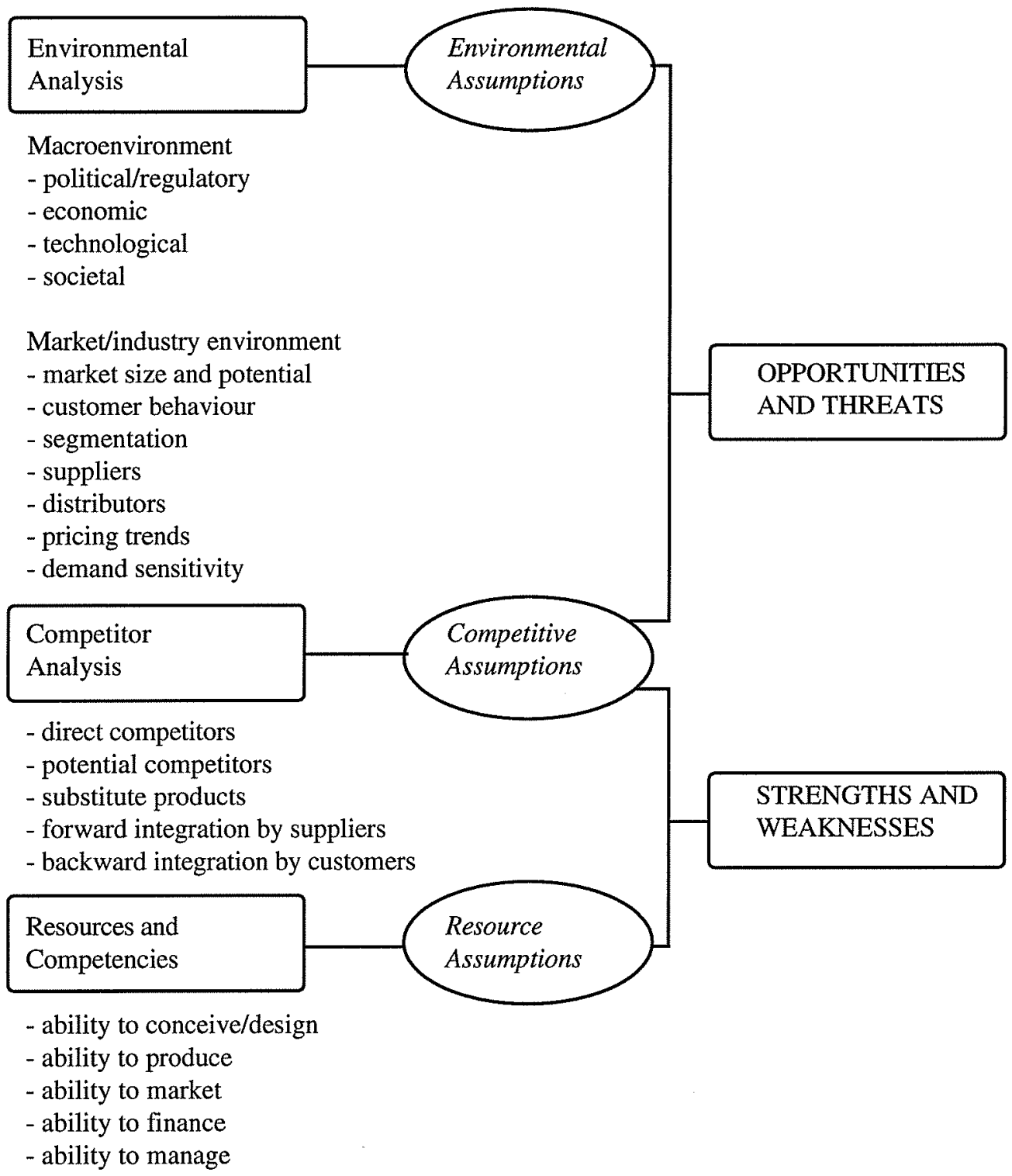

Exhibit 2.1 Elements of a Situation Assessment

Successful market strategies may be analogous to the military strategy of isolating the battlefield in that they segment to total market in a way which maximises your strengths while minimising your competitors'. ${ }^{13}$ Transportation firms have a strong motivation to seek monopolistic control over some of their territory. ${ }^{14}$ Several critical questions flow from this:

\footnotetext{
13 Day (1984), p71

14 Nyanthi (1993), p1029. The pressure for this type of monopolistic control could arise from airline's high fixed costs and low variable costs.
} 
(1) What is the basis for choosing the segments which the firm currently serves?

(2) What is the current and forecast performance within the served market?

(3) What are the likely threats: from present competitors or potential competitors in terms of achieving cost advantages, offering substitute technologies or providing better service?

(4) What is the scope of the business definition?

Some of the answers to these questions lie in an hierarchical level of analysis which distinguishes products or services produced by the firm in terms of product types, product variants and different brands.

The ability of an airline to vary its strategy by targeting a group of customers or a geographic region, increases the airline's strategic options to the point where it could focus on that group or region using a separate strategy. 15

In the airline industry product types may be broadly identified as different classes of service, for example, first, business and economy. A related concept is product variants. Within this category we could identify economy class and discount class fares as variants because although similar levels of inflight service are provided there is a high probability that there is more short-run substitution between discount fares and economy fares than discount fares and business or first class fares. ${ }^{16}$ At the industry level brands are proceed on the same specific product variant by different firms. In the airline industry brand differentiation exists, for example, between Qantas' business class and Garuda's business class and these brands are direct and immediate substitutes.

Putting these concepts together in Exhibit 2.2 we can develop the following diagram of hierarchical product structure for the airline industry. ${ }^{17}$

\footnotetext{
15 Porter (1985)

16 Cain and Harbison (1993), pp156-7, show that since deregulation in the US, although there has been an increasing number of passengers travelling on discount fares, the complexity of fares and fare constructions has increased. This is still a contentious issue.

17 Day (1984), p76
} 


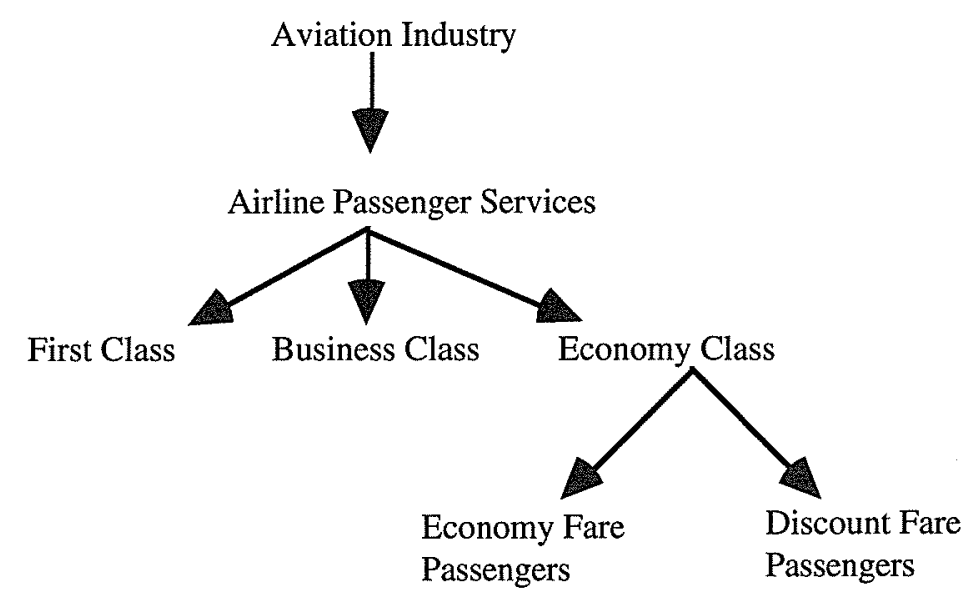

Exhibit 2.2 An Hierarchical Analysis of Market Segmentation

The driving factor behind the identification of market segments is to yield customer segments that are measurable, accessible, different, substantial and durable so that airlines can develop a segmentation for providing their services by choosing key segment descriptors. ${ }^{18}$

\section{Marketing}

Marketing is another crucial element in the management of airlines. It is one of the crucial non-price elements of competition between airlines as they strive to gain an advantage over their competitors. ${ }^{19}$ At a general level marketing may be considered as the direction of the flow of goods and services from producers to consumers. Marketing is not confined to any particular type of economy or just to profit oriented businesses. However, marketing will be examined in the context of Western business organisations in this paper. Marketing was once seen as encompassing only sales, advertising and perhaps market research with the primary function of marketing staff being to maximise sales volume. ${ }^{20}$ Marketing as a concept has been considerably broadened to include product development, customer communications, and customer services. In some organisations

18 Street, Smith and Spence (1993), p168, have identified passenger market segmentation and brand loyalty as potential strategic barriers to entry.

19 Tisdell (1986), p259

20 Hardy (1987), p123, notes that within the marketing approach promotions are a major tool used by firms to raise the level of demand for a product. 
marketing managers have also been given responsibility for credit, physical distribution, public relations, and research and development.

As a business function, marketing usually examines four key functions: pricing, product determination, placement and promotion. Product determination establishes what is to be produced. Such determinations are usually made in conjunction with the company's manufacturing, engineering, and finance departments. Promotion refers to the information dissemination process concerning the product and the appropriate advertising strategy which needs to be employed. ${ }^{21}$ All of these elements are embedded in the operation of airline services.

Another important aspect is placement, how to ensure the product reaches the market in the most timely, efficient and effective manner possible. There is an argument that airlines will tend to pursue minimum product differentiation in order to attain market share. The principle of minimum product differentiation, Hotelling's rule, suggests that in an oligopolistic market, such as an airline market, firms will cater for median tastes. ${ }^{22}$ Timeliness of product distribution is critical to airlines because it is one dimension along which airlines compete. ${ }^{23}$

Pricing is critically important as well because even if the product has superior qualities to its competitors, and the market is aware of its existence, and it is readily available through effective distribution channels, a poorly priced product can reduce sales and hence corporate profitability.

The sales process is critical to the development of the market. In this respect retailing and wholesaling are important. In many countries small independent merchants still form the basis of the retail distribution network for goods. Chain stores and supermarkets developed as the advantages of centrally managed stores became apparent. Some retailing is done without stores, for example through cataloguing or vending-machine operators. Wholesaling is another critical part of

21 Petersen and Lewis (1990), pp423-4, suggest that the type of advertising is influenced by the market structure. Advertising expenses are most likely to be high when the industry structure is one of monopolistic competition, where firms sell differentiated products, because advertising is one way to attain product differentiation.

22 Tisdell (1986), p263. This is primarily because each airline will pitch its product at the passenger group which fits a median passenger demographic profile. The consequences of an airline offering its main product to a non-median group would be to allow another airline greater market access and hence market share by adopting the median passenger profile.

23 Street, Smith and Spence (1993), p171, note that airline's computer reservation systems often confer considerable market pwer and ultimately can influence the distribution of seat bookings. 
the distribution process and consists of selling to other business firms, either for resale or business use, usually in bulk and at less than retail prices. The airline industry is increasingly becomeing part of a vertically integrated chain. This will be discussed in some detail below.

The channels through which goods are marketed to industry are different to the forms of marketing used for final consumers. In the airline industry, airline capacity is either sold as individual seats or as part of a package. In addition, this capacity is either marketed through airline reservation systems, through airlineowned travel agencies or independent travel agencies. Each channel employs different distribution techniques.

Market research is an important part of the marketing process. The ability to research the consumer and form an accurate view of comparative performance of an airline is vitally important the development of the most cost-effective service to meet passenger demand. ${ }^{24}$ It involves the application of scientific techniques to the solution of marketing problems or opportunities. It is concerned with channels of distribution, with promotion and pricing, and with the design of products and services to be marketed. ${ }^{25}$

Merchandising and product development are another part of the marketing process. The constant replacement of products with new or altered products as a result of changing consumer tastes and expectations, technological innovations, and competitive pressures has focused the attention of professional marketers. Product design, product line and mix, packaging and branding, and advertising are critical to the successful sale of a firm's output. Three forms are product design have been identified: innovation, alternation of an existing product, and the development of new applications for an existing unchanged product. There is a wide range of participants in many product design projects. The product line and product mix are another aspect of product development which is important.

These aspects of marketing goods are important in the analysis of marketing airline services.

24 Hardy (1987), p21

25 The basic research steps are: (1) preliminary analysis of relevant factors and variables based on an extensive data search; (2) definition of the problem; (3) development of a study plan for the research, based on data organisation; (4) data collection and tabulation; (5) interpretation of the results; and (6) presentation of results to management, including assistance in following up study conclusions and recommendations. 


\section{Chapter 3 Theories for Airline Management}

The approach airline managers adopt to a particular market situation hinges critically on the information that is obtained through a situation assessment and the management paradigm which is employed to analyse that information and reach strategic decisions. In examining strategic market planning and airline management strategies we delve into the rationale behind the use of the information collected through the situation assessment in the airline industry, setting a framework to analyse the relationship between market share and profitability. We also examine some traditional management tools which have direct application to the question of the profitability-market share relationship.

\section{Strategic Market Planning}

Peter Drucker has stated, "A decision is a judgement. It is a choice between alternatives. It is rarely a choice between right and wrong. It is at best a choice between "almost right" and "probably wrong" - but much more often a choice between to courses of action neither of which is probably more nearly right than the other". 26

Strategy originally had a military context which related to the effective use of military forces based on knowledge of the enemy's strength, the battleground's physical features, and the resources available to the commander. This concept of strategy has become an analogy for business. ${ }^{27}$ One major difference between 
warfare and business, however, is that business is not necessarily a zero-sum game. ${ }^{28}$ A strategy statement by a business will have the following characteristics:

- a definition of the business,

- the strategic thrust of the business, describing the investment strategy and the source of competitive advantage,

- the supporting strategic actions to execute the strategic thrust, and

- the tactical or operating programs that outline steps required to implement the strategy.

Porter notes that "a common practice in strategic planning is to use market share to describe a business unit's competitive position ... industry leadership is not a cause but an effect of competitive advantage." 29 Underlying the fundamental profit-market share choices faced by airline managers is the need to meet the challenge of strategic market planning which involves financial evaluation, consideration of alternatives, broad coverage of the issues and the formulation of a long-term strategy. ${ }^{30}$ There are four major challenges which are related to this fundamental choice for airlines. ${ }^{31}$

First, airline management has to achieve an external orientation so that there is continual drive for new competitive advantage sources within existing markets. In Australia the rapid responsiveness of domestic airlines during the fare wars immediately after domestic deregulation suggested that airlines were becoming externally oriented. This is also demonstrated by the successive introduction of frequent flyer programs. Although Compass Airlines rejected introducing a frequent flyer program, it was forced to respond to Ansett and Australian's challenge. 32

28 Nyanthi (1993), p1029, suggests that a game theoretic approach, where airlines take strategic manoeuvres against other in an attempt to gain competitive advantage, is another way of examining this issue.

29 Porter (1985), pp25-6

30 Grieve Smith (1985), p115. Strategic planning provides a broad overview and assessment of the operations of an airline and is critical in formulating the competitive strategies that the airline will adopt to become profitable and/or become a market leader.

31 Day (1984), pp205-6

32 This is a good example of the pressure of non-price competitive responses that occurs in many industries, but particularly in the airline industry. In an oligopolistic industry price variations are not profitable as a competitive device according to Tisdell (1986), p279. 
Second, management has to build a commitment to planning through the involvement of at least line managers in the planning cycle. This can be seen in Qantas Airways' introduction of total quality management and the involvement of staff in the planning process.

Third, creativity must be fostered rather than stunted. The key point of this challenge is to facilitate a process which encourages ideas and free thinking and avoids the premature closure of strategic options before managers have developed a broad consensus.

Fourth, developing and maintaining a capability to effectively adapt to changing circumstances. This could be simply developing an ability to adapt incrementally to change in the way that Qantas has faced international competition or it could involve a quantum strategic leap, such as merger of Qantas and Australian, which will allow the merged carrier to provide a seamless international-domestic service and open new strategic options.

So how do we evaluate strategic options which confront these challenges? There are a range of criteria which can be used to systematically evaluate how improvements based on a strategic market plan affect company performance: suitability, validity, consistency, feasibility, vulnerability and potential rewards. ${ }^{33}$

Suitability addresses the question of whether or not there is a sustainable competitive advantage. For example, with the Australian Government's policy of multiple designation of Australian carriers on international routes, Qantas' strategy of marketing itself as the Australian carrier will not be sustainable in the long run, although it is presently well established as Australia's identifiable international carrier.

Validity questions the key assumptions and whether or not they are realistic. In this context airlines need to evaluate current views in the marketplace about declining numbers of first class and business class passengers. High yield passengers are crucial to an airline's profitability. A general industry view is that these passenger proportions will decline, however, there is no widespread acceptance for the reasons behind this forecast decline. 
Consistency examines whether or not the basic elements of the strategy and consistent with each other and with corporate objectives. For example, is Qantas' merger with Australian Airlines consistent with the goal of providing a seamless international-domestic service and generating savings through synergies?

Feasibility questions whether the strategy is a appropriate to available resources and whether or not the basic strategic premises are understandable and acceptable to line managers. In this instance a carrier could examine its fleet re-equipment program to ensure that the appropriate level of capital is being expended. ${ }^{34}$

Vulnerability examines the sensitivity of the strategic plan to key assumptions, questions the implications of the failure of the strategic plan, and assesses the consequences of meeting the plan. When Boeing introduced the B747, for example, its management knew the outcome of the project would determine whether or not the company survived.

Potential rewards assesses whether the outcomes are satisfactory in meeting the goals and the business and whether or not adjusting the objectives is acceptable to stakeholders. For example, the high debt and high beta airline companies attract very low ratings and therefore face a high cost of capital. So a policy of restructuring corporate debt might provide some shareholder benefits. ${ }^{35}$

\section{Airline Management Strategies}

What are the types of management strategies which could be used by airlines? Like most businesses there are a range of generic performance improvement strategies in terms of increasing sales volume or improving profitability. ${ }^{36}$

Generic strategies relating to increasing sales volume focus on market penetration, product and market development, and forward integration. ${ }^{37}$

\footnotetext{
34 The bottom line is a critical part of the overall strategic approach of an airline. What an airline proposes to do in terms of investment has to be credible and achievable. Essentially any investment has to produce an acceptable rate of return. Hardy (1987), p235

35 Lawrinsky (1993), p205

36 Day (1984), p102

37 Day (1984), p103
} 
Sales volumes is affected by the dimensions of the business definition as shown in the Exhibit 3.1 below, which gives an indication of the challenges faced by airline managers.

Stages of
Value-Added

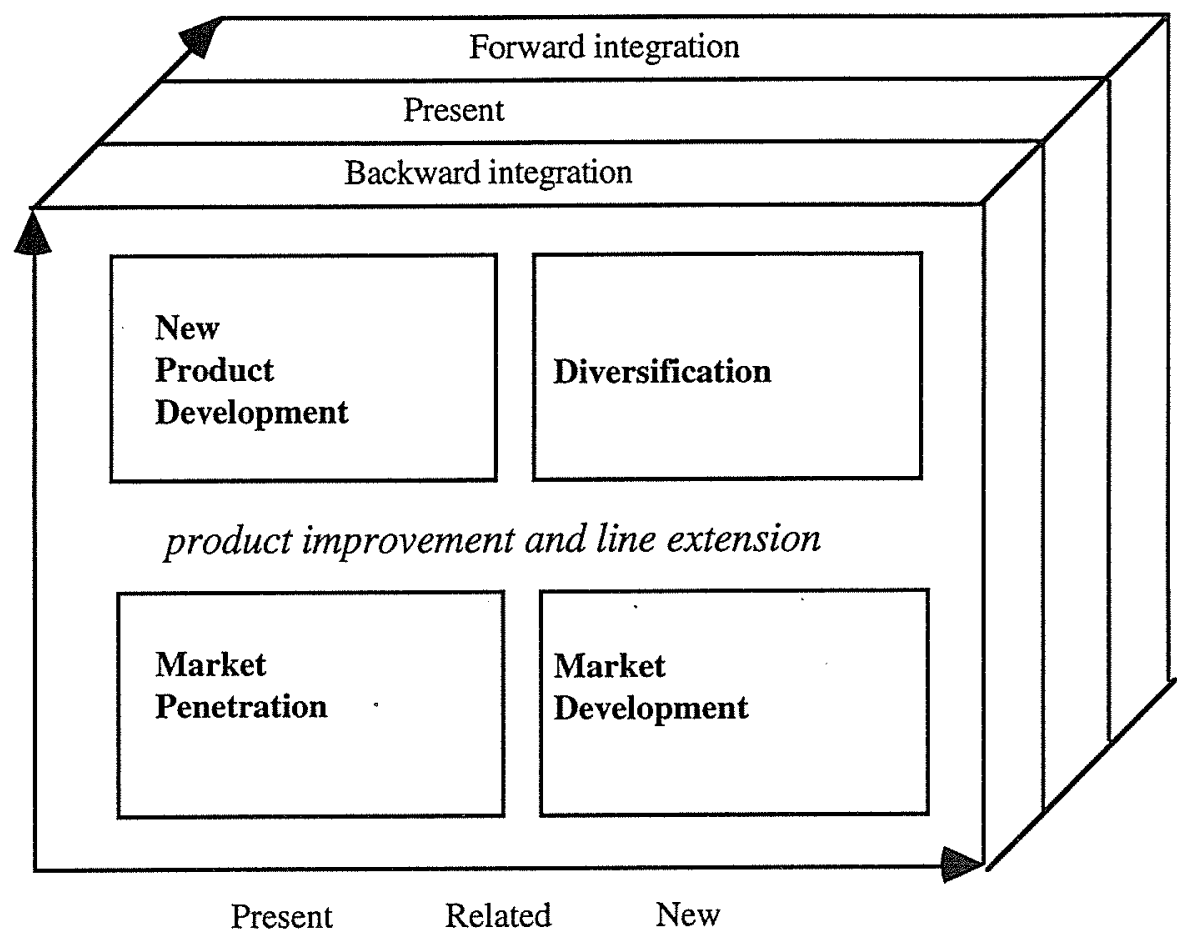

Customer Segments

\section{Exhibit 3.1 Directions for Expanding the Business Direction}

There are three main tactics which underpin a market penetration strategy. First, increase the choice of a particular carrier and increase customer loyalty from the existing customer base. Second, attract competitors' customers. Third, discourage new and existing customers from flying with other airlines through raising the commercial stakes and preemptive pricing or capacity additions.

Australian and Ansett have employed the first two tactics in response to competitive pressures arising from the deregulation of domestic aviation. Australian, for example, provided luggage delivery services to selected hotels, valet parking and airport conference facilities, and made an arrangement with selected hotels for automatic room upgrades for their first class and business class passengers. ${ }^{38}$ 
Airline frequent flyer programs, discount pricing offers and aircraft acquisition programs are often used as part of the third tactic. Frequent flier programs are designed to reward brand loyalty and impede contestability within the industry. ${ }^{39}$ Total domestic Australian industry capacity increased 16 per cent prior after deregulation, with the new entrant, Compass Airlines, providing 9 per cent of that new capacity. 40

Product development involves the development of new services within the organisation. The former Australian Airlines, for example, pioneered flights to holiday resorts such as Yulara. ${ }^{41}$ It also involves joint ventures, such as Ansett's frequent flyer program which plugs into an international network of overseas carriers.

Market development is another way of increasing sales volume by entering new segments. This may be through offering flights to new destinations, in the way Compass offered direct flights between Perth and Cairns or through offering a completely new level of service.

Forward integration is another strategic path airlines have pursued by offering connections with car rental companies and hotel chains. This is part of adding value in the travel process and locking customers into one seamless travel service. This issue is discussed in further detail in Chapter 4.

In terms of improving airline profitability there are five tactics which can be employed: increasing yield, reducing costs, vertical integration, reducing investment intensity and attaining greater selectivity or focus. ${ }^{42}$

Airlines have tried to increase their yields by improving their sales mix. This primarily means trying to attract more full fare paying business class passengers. They have also reduced distribution margins by increasing commissions to travel agents and have selectively increased the price of air fares on travellers who have a more inelastic demand for travel.

\footnotetext{
39 Levine (1987). The frequent flier scheme impedes contestability through: (1) linking customers to rewards in non-linear ways; (2) creating economies of scope through large networks on which passengers can accumulate points; and (3) creating an incentive for business travellers to extract a high fares from their employers to capture frequent flier benefits.

40 BTCE (1991a), p25

41 BTCE (1991a), p20

42 Day (1984), p103
} 
Australian carriers have managed to reduce costs through greater efficiency. For example, employment in the industry has either remained static or airlines have shed staff, as is the case for Qantas, at a time when a record level of domestic passengers are being carried. All airlines cut their pilot numbers significantly in the wake of the 1989 pilot's dispute while Ansett and Australian almost doubled their flying hours per pilot. $A$ ustralian estimated that it cut pilot costs by about $\$ 21$ million. 43 In addition most carriers are making greater utilisation of their aircraft. ${ }^{44}$ Ansett Australia, for example, has announced that from September 1993 it will be carrying passengers overseas to Bali using aircraft which would have been sitting on the tarmac on weekends. There has also been a round of cost cutting in the industry.

Vertical integration has been another method used by airlines to boost profitability. Forward integration, discussed above, is one element: Another important aspect has been backward integration which has involved the acquisition of feeder airlines and travel agencies. The acquisition of travel agencies by major domestic airlines in Australia has been the main vertical integration strategy which has been pursued since deregulation of domestic aviation in October 1990.45

Related to greater capacity utilisation is the reduction in investment intensity. Airline plans in the deregulated domestic environment are tailored more closely to forecast market trends. In 1991, for example, Australian Airlines held on to its Boeing 727 aircraft because the market was poor and it leased out its newer Boeing 737 equipment. 46

Airlines have also sought greater selectivity or focus in their operations. Eastwest Airlines, for example, has tended to concentrate on carrying holiday makers to Queensland from the southern States of Australia as a way of achieving greater segment rationalisation. In terms of distribution rationalisation, Qantas and Australian are pursuing greater fleet commonality, which is aided by the fact that both airlines have a Boeing fleet and staff retraining to ensure compatibility across both fleets is minimal. This contrasts with the wide range of equipment operated

\footnotetext{
43 BTCE (1991a), p27

44 DOTAC (1992)

45 Cain and Harbisnon (1993). This is a questionable strategy if the travel agencies are not acting in the interests of the acquiring airlines because then the investment becomes one which focuses solely on the returns generated through normal agency business with no demonstration of synergistic benefits. 46 BTCE (1991a), p28
} 
by Ansett and the difficulties it would have in switching aircraft on short notice on a particular route. The product lines offered by both major domestic carriers have been rationalised as well. Given the very small number of first class passengers both airlines have moved their business class passengers into the first class section of the cabin, freeing up additional seats which could be sold on a marginal cost basis, to recover operating costs.

\section{Developing a Postional Advantage}

Airline marketing strategies have to fit into the overall management framework of the organisation. A study of 62 American corporations identified several basic attributes which appear to account for corporate success. ${ }^{47}$ Successful companies are close to customers and are action-oriented with a bias for getting things done. Senior management are close to 'front-line' staff and have well-defined basic philosophies which are applied in innovative ways. The corporations tend to focus on core operations and have simple structural forms and systems with few senior staff. These companies have simultaneous loose-tight properties with operational decentralisation but strong, centralised control over a few core values.

Attaining a competitive advantage is an important objective of an airline strategy. The sources and consequences of competitive advantage are shown in Exhibit 3.2.48 Positional superiority is the outward evidence of a competitive advantage which may be analogous to barriers to entry.

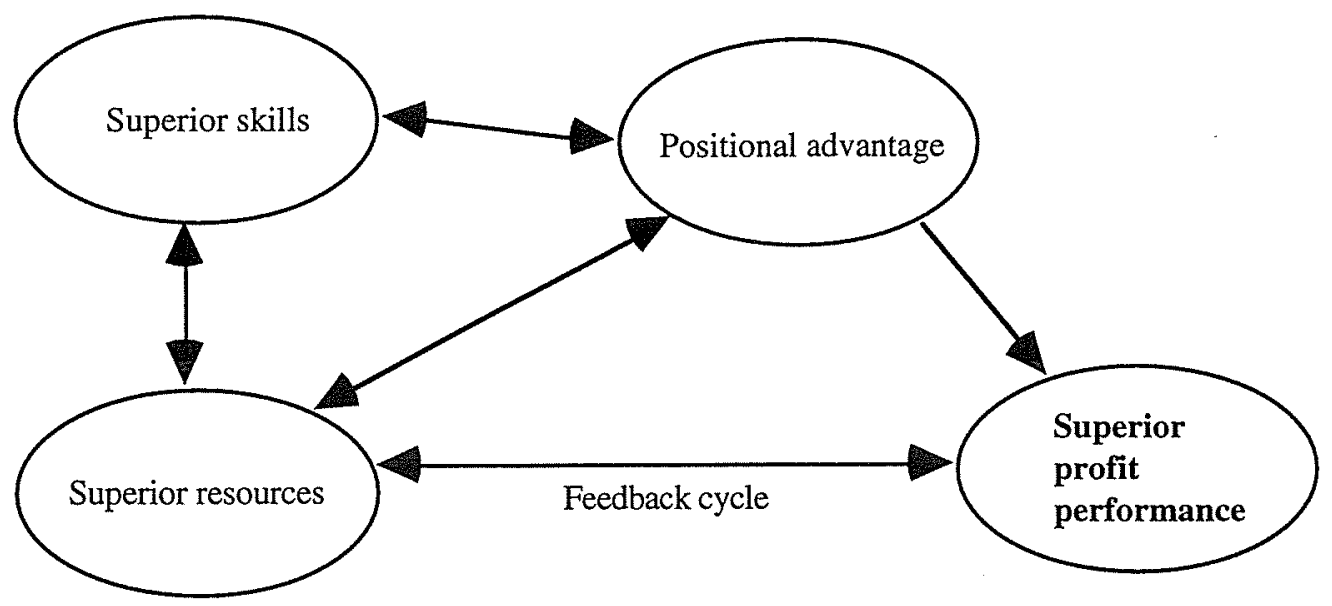

\section{Exhibit $3.2 \quad$ Positional Advantage}

47 Peters and Waterman (1982)

48 Day (1984), p26 
The key positional advantages are superior cost position, a differentiated offering, or operating in a protected niche. Differences cannot be profitably exploited unless they can be converted into benefits perceived by a sizeable customer group which these customers value and are willing to pay for, and cannot be readily obtained by competitors.

A differentiated offering is the second positional advantage which may be generated in a number of ways. ${ }^{49}$

An airline could create a unique product or service, like People's Express in the US which simply offered seats between Los Angeles and New York on a no frills basis. the no frills options is discussed in Chapter 4.

Some airlines provide superior in flight service, such as Qantas or Singapore Airlines. The insuperable barriers to entry are based on people capital tied up in ironclad traditions of service, reliability and quality. 50

United Airlines and many other national carriers utilise strong brands names.

Qantas provides superior product quality through fully integrated ticket reservation and car hire facilities and it is also a full line producer, offering a wide range of fares and holiday packages. The Ansett Group is also much more than an airline company. It is more diversified, earning more than 40 per cent of its revenue from sources other than airline operations. 51

Some carriers are technologically innovative, offering the latest types of slumber seats or personal video facilities to passengers. When Compass Airlines first commenced operations in Australia, for example, it was the first airline to introduce in-flight videos and had the most generous seat pitch. ${ }^{52}$

Most carriers strive to attain a wide distribution coverage through access to computer reservation systems and major travel agencies in many countries. ${ }^{53}$

49 Day (1984), pp27-8

50 Peters and Waterman (1982)

51 BTCE (1993), p28

52 BTCE (1991a), p23

53 Street, Smith and Spence (1993), note that travel agencies have an advantage over airline ticketing offices in providing efficient ticketing for all airlines and these offices are able to put together 
The sources of positional advantage are varied but may also be categorised as skill or resource advantages. ${ }^{54}$ Human resource capabilities embrace specialised knowledge of segments; customer service orientation; design expertise; applications experience; trade relationships; ability to utilise relevant technologies; systems design capability; and fast and flexible response capability. For example, Qantas Airways might be able to train its cabin staff to provide superior service providing that customer service orientation which would give it a competitive advantage or through an acquisition program it could have the most modern fleet of 747 aircraft in the region which would demonstrate its ability to utilise relevant technologies.

Superior resources may involve: distribution coverage; financial structure and access to capital; shared experiences with related businesses; low-cost manufacturing and distribution systems; production capacity; and ownership of raw materials or long-term supply contracts. Airport terminal access is one contentious resource issue through which airlines seek to gain a competitive advantage. ${ }^{55}$

Entrants may find it difficult to obtain financing due to the risk perceived by creditors. ${ }^{56}$ Clearly the amalgamation of Qantas Airways and Australian Airlines and its subsequent privatisation has led to the development of a superior national aviation resource through shared business experiences and an improved financial structure with enhanced access to capital. 57

The basis for these positional advantages is superiority in supporting skills and resources. ${ }^{58}$ Three main competitive positions can be identified from which airlines can operate:

travel packages which include the airline. In Australia about 50 per cent of domestic airline reservations are made through travel agencies.

54 Day (1984), p30

55 Forsyth (1993), p198, has noted that it is difficult to devise an incentive/ regulatory regime which is practical, simple and promotes efficiency. Airports tend to involve a combination of problems, whilst not especially individually unique, which become difficult to deal with simultaneously. 56 Tirole (1990)

57 As Lawrinsky (1993), pp204-5 has noted, airline stocks exhibit high volatility relative to the rest of the economy. At a time when it is difficult to value airline stocks, further amalgamations and extensions of cross-border shareholding, corporate debt restructuring and floats of new or privatising companies will drive the demand for these valuations.

58 Day (1984), p32 
- least-cost producers like Compass Airlines in Australia or People's Express in the US which offer 'bare bones' services comprising narrow product lines at discounted prices,

- $\quad$ specialists like Eastern Australia Airlines, which concentrates on specific east coast regional markets and has a strong customer-tailored service, and

- full-line national distributors like Ansett Australia or Australian Airlines which offer a full product range requiring heavy initial capitalisation, strong decentralised functional support and a broad range of management skills.

Porter in his book Competitive Strategy, explains differences in returns to firms in terms of five leading factors lead to divergences with an economic approach to free competition. They are barriers to entry, the degree of industry competition, substitute product pressures, buyers' bargaining power and suppliers' bargaining power. ${ }^{59}$ In the key element of barriers to entry particular focus is placed on scale economies, product differentiation, switching costs, access to distribution channels, cost advantages of established producers and government regulation or licensing. Each of these elements play a critical role in formulating airlines' business strategies.

How this competitive advantage is sustained will depend on the reaction of competitors and whether or not they can cope with or nullify this advantage. Duration of these advantages ranges from long term patent-protection to short-term price advantages which are also eroded as customer requirements change. ${ }^{60}$ In the airline industry investment strategies specify the requirements for the funds needed to support the strategic thrust and the outcomes expected from that allocation of funds. ${ }^{61}$ While there are many possible investment strategies, the choice is usually made from one the following broad categories: 62

- Invest to enter: this is the platform from which Compass Airlines intended to compete with Ansett and Australian.

59 Grieve Smith (1985), p98

60 Day (1984), p32

61 Street, Smith and Spence (1993), p169, give examples of the difficulties facing start up airlines in the deregulated Australian markets. Although Compass Airlines (Mark 1) was oversubscribed in raising $\$ 65$ million in equity capital, Compass had originally proposed to raise $\$ 100$ million. Compass Airlines (Mark 2) sought $\$ 50$ million through a public float and ended up being undersubscribed by 46 per cent.

62 Day (1984), p34 
- Invest to build: Eastwest Airlines pursued this investment policy initially to expand its regional operations.

- Invest to rebuild: the recapitalisation of Qantas has given that airline an opportunity to rebuild its fleet by acquiring more modern aircraft.

- Build selectively: both Ansett and Australian have invested in facilities, such as ground side airport lounges, for premium class passengers where returns are larger.

- Protect current position: the two major domestic Australian airlines have also invested in new terminal facilities and purchased major travel agency chains to protect themselves from competition by new entrants.

- Selectively manage for earnings.

- Harvest.

- Exit/divest.

The complete market strategy will have the basic elements of a business definition plus the strategic thrust, however functional strategies are required in order to form a complete strategy statement. Exhibit 3.3 on the following page shows the interaction of those elements. 


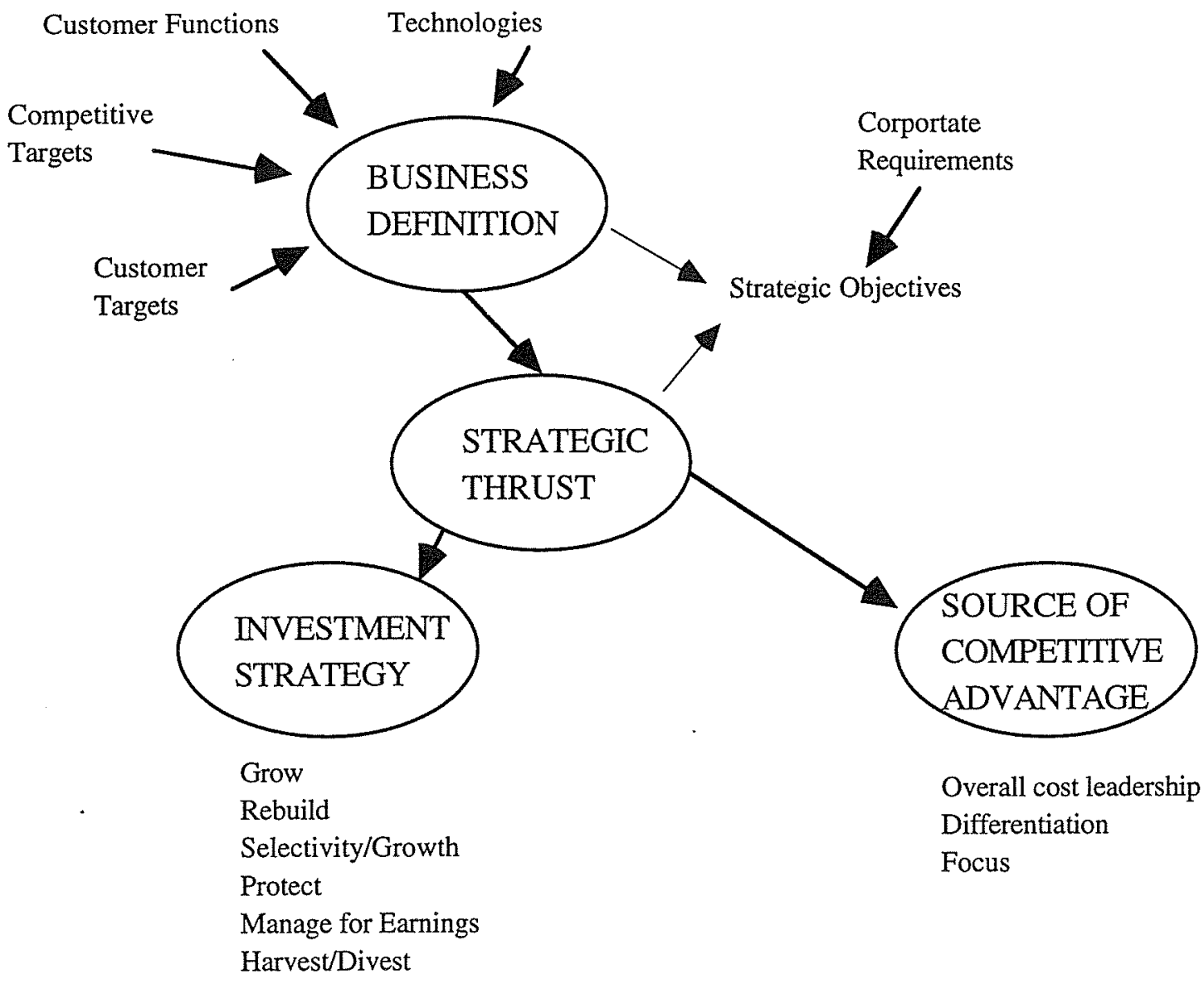

SUPPORTING FUNCTIONAL STRATEGIES

Exhibit $3.3 \quad$ Elements of a Market Strategy 


\section{Chapter 4 Elements of Market Share and Profitability}

Building on the key elements of a situational assessment for the airline industry, this Chapter focuses on two key organisational goals outlined in Chapter 2: market share and profitability. The critical concept of value chains is introduced to integrate the competitive strategies in the airline industry in a framework which is relevant to profitability and market share concepts.

\section{Market share}

Market share is used in performance evaluation, short-run planning, strategic planning and analysis of threats and opportunities. It is a measure which has multiple dimensions depending upon the choice of variables which have to be measured.

No other non financial measure of the position of a business is as widely used as market share. It is a direct indicator of the relative competitive position of a business and it has exceptional diagnostic value. ${ }^{63}$

The concept of cumulative market share is sometimes mentioned as a concept in portfolio planning. The view is that the business with the largest market share will tend to be the most profitable because it will have the lowest costs. This may not be the case in other than very high growth industries since cost reductions as the firm grows becomes very small and is often masked by other factors. ${ }^{64}$ The idea

\footnotetext{
63 Day (1984), p96

64 Pearson (1985), pp45-6
} 
of buying market share is irrelevant unless the purpose is to build a monopolistic position and use that position to exploit consumers. 65

Industry conditions tend to play an important role in determining whether or not there is a relationship between profitability and market share. Michael Porter, in Competitive Strategy: Techniques for Analysing Industries \& Competitors, suggests that "the relationship between the profitability of larger and smaller market shares depends on the industry ... followers were noticeable more profitable than leaders in 15 of 38 industries. The industries in which the followers' rates of return were higher generally appear to be those where economies of scale were not great or absent (clothing, footwear, pottery, meat products, carpets) and/or those that are highly segmented (optical, medical, ophthalmic goods, liquor, periodical, carpets, toys and sporting goods). The industries in which the leaders' rates of return are higher seem to be generally those with heavy advertising (soap, perfumes, soft drinks, grain mill products, ie. cereal, cutlery) and/or research outlays and production economies of scale (radio and television, drugs, photographic equipment). This outcome is as we would expect."66

This is reinforced a study of low market share-high profitability firms and high market share-low profitability firms. ${ }^{67}$ Low market share-high profit firms typically were involved in the sale of standard products and supplies without the provision of custom features or auxiliary services in a marketplace characterised by high sales turnover, high value added and a large number of competitors. High market share-low profit firms were typically located in slowly growing fragmented markets and these firms produced lower value added goods. The benefit of high and low market share depended on a range of factors like market characteristics, the products offered by the firm and the firm's competitive strategy. ${ }^{68}$

The airline industry fits the characteristics of a high growth industry which produces a varied range of transport services for passengers. It exhibits high advertising rates in order for airlines to differentiate their products and has potential economies of scale in aircraft operation and economies of scope through networking, hubbing and strategic alliances. This fits Porter's template for industry leaders' having higher rates of return and establishes why an airline

\footnotetext{
65 Pearson (1985), p46

66 Porter (1980), pp147-8

67 Woo and Cooper (1983)

68 Grieve Smith (1985), pp 101-2
} 
management strategy needs to address the market share issue in order to remain competitive and profitable as an organisation. There are a range of factors which would mitigate against airlines being able to effectively compete on a range of other factors. Four are briefly identified below to suggest the importance that an airline management strategy has in the performance of that company.

Major domestic and international airlines have access to the same capital equipment, Boeing and Airbus Industries supply aircraft to airlines operating in te same markets and are capable of fitting out these aircraft according to the operator's specifications. In fact, indications are that Boeing and Airbus are likely to collaborate on the development of a very large commercial transport which would be twice the size of a Boeing 747-400.

Terminal access at either end of the journey is invariably shared with competitors unless the airline decided to build a dedicated terminal. Usually this is associated with a major hub, such as Delta Airlines' hub at Atlanta, Georgia. In some countries access to terminal facilities is actually restricted due to airport congestion this is the case in Japan and some European countries.

Major airline competitors now have access to common computer reservation systems. in the past American Airlines was able to use the Sabre reservation system to gain a competitive advantage over other carriers through introducing screen display bias. In Congressional testimony 92 per cent of travel agent ticket sales in the US came from the initial pro-carrier screen. ${ }^{69}$ The airline now realises that it is far more profitable to equitably service the reservation needs of other carriers through this system. It is extremely difficult to obtain sales channels which are not open to competitors. In Canada, for example some 70 per cent of airline tickets are sold by travel agents and 80 per cent of travel agents are connected to a computer reservation system. ${ }^{70}$

On international routes the system of bilateral aviation treaties effectively locks most countries into an even market share within which several carriers from one country may compete. Full international competition is still not possible in terms of the addition of extra capacity although airlines now operate in a more liberal

69 Tretheway and Oum (1992)

70 Cain and Harbison (1993) 
international fare structure as evidenced by heavy discounting on the UK-Australia route, the Australia-US route and the US-UK route.

\section{Enhancing Profitability}

So what are the measures by which airlines can enhance their level of profitability? There are two ways to view the profitability enhancement. One is through a capital model as shown in Exhibit 4.1 and the other is through a market analysis of supply and demand factors. ${ }^{71}$

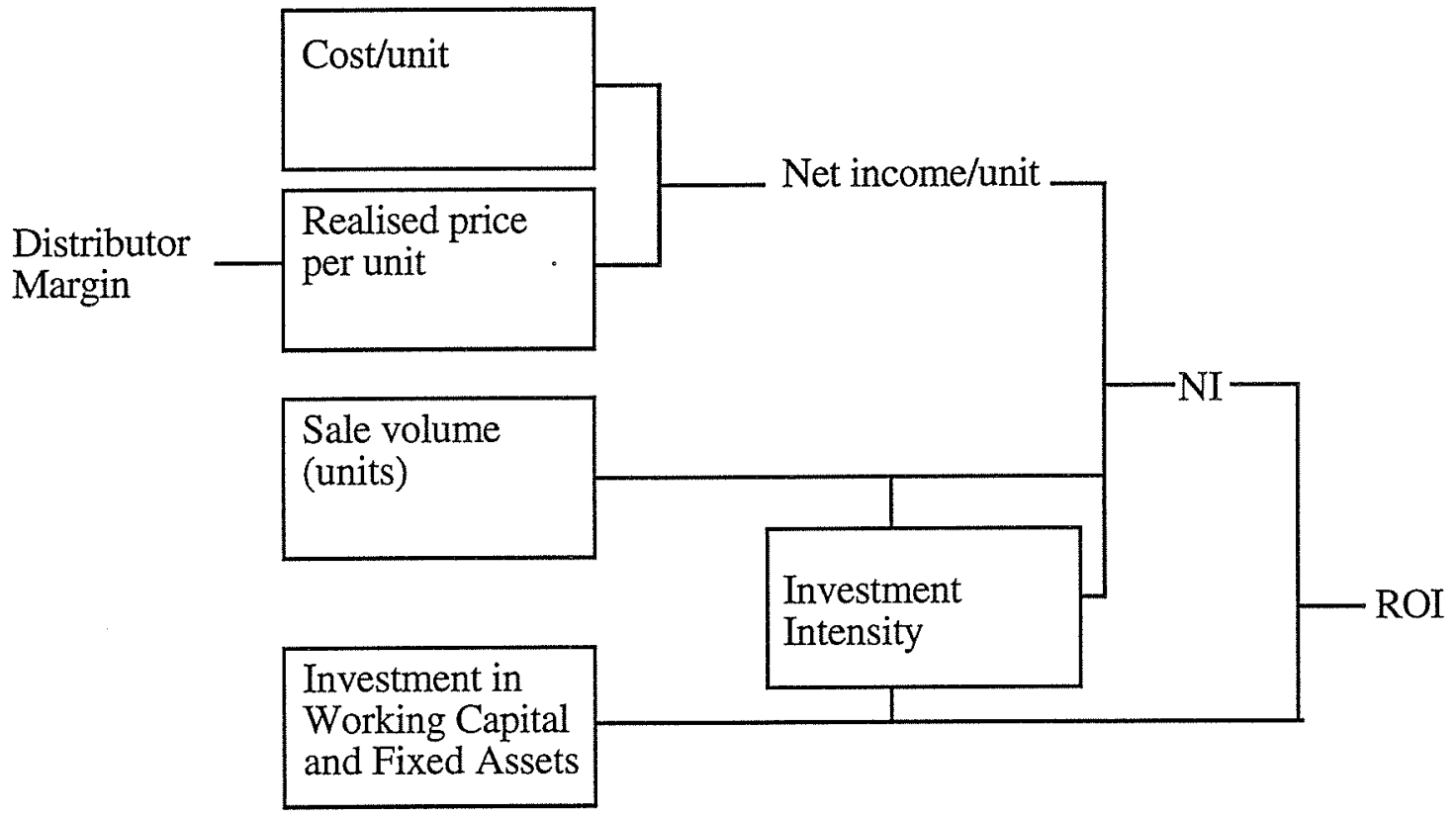

Exhibit 4.1 Components of Profitability

In the discussion so far we have concentrated on short-term profitability, ignoring, conveniently, investment in aircraft and airport terminals, although it has been recognised that equipment and assets which airlines hold will affect their level of profitability.

Yield management is a particularly critical element in enhancing airlines' profitability. In the first instance it involved the segmentation of travellers into 
various categories in order to achieve the highest average fare possible. Detailed knowledge of the market is required to achieve this level of segmentation and airlines operate sophisticated yield management systems to ensure that their margins are maximised. An across-the-board price increase is risky, versus selective increases, because other firms may not follow and the firm raising prices may lose market share. ${ }^{72}$ It is also risky to increase prices at the expense of the distributors' margins. In the airline industry, for example, there would be an incentive for travel agents, as the main distributors of airline seats, to switch to other carriers. The attention airlines pay to the distribution and wholesale segments is indicated by commissions which are paid to travel agents. After deregulation of domestic aviation, for example, Ansett and Australian Airlines increased their commissions to travel agents. ${ }^{73}$

Unit-cost reductions are the other element in enhancing profitability. There are a wide range of ways of achieving this in the airline industry. One way is by obtaining more efficient aircraft and other capital equipment to improve production efficiencies. The recent fleet re-equipment by Ansett and Australian are evidence of this. Another way is through the substitution of aircraft, in the way Qantas now uses smaller aircraft on the domestic legs of its international flights, or contracting out elements of the production process.

The computerisation of airline management information systems, critical for yield management, also means that customer database profiles are available and work flow patterns can be optimised.

Another way of reducing unit costs is through increased capacity utilisation. This has certainly been the case in Australia since deregulation of domestic aviation services in October 1990. Aircraft annual flying hours have increased and domestic carriers have attained higher load factors. ${ }^{74}$

So how is the relative profitability of one carrier assessed against its competition? By examining demand and supply factors in the diagram below we can obtain a better picture of the factors affecting profitability. ${ }^{75}$ 


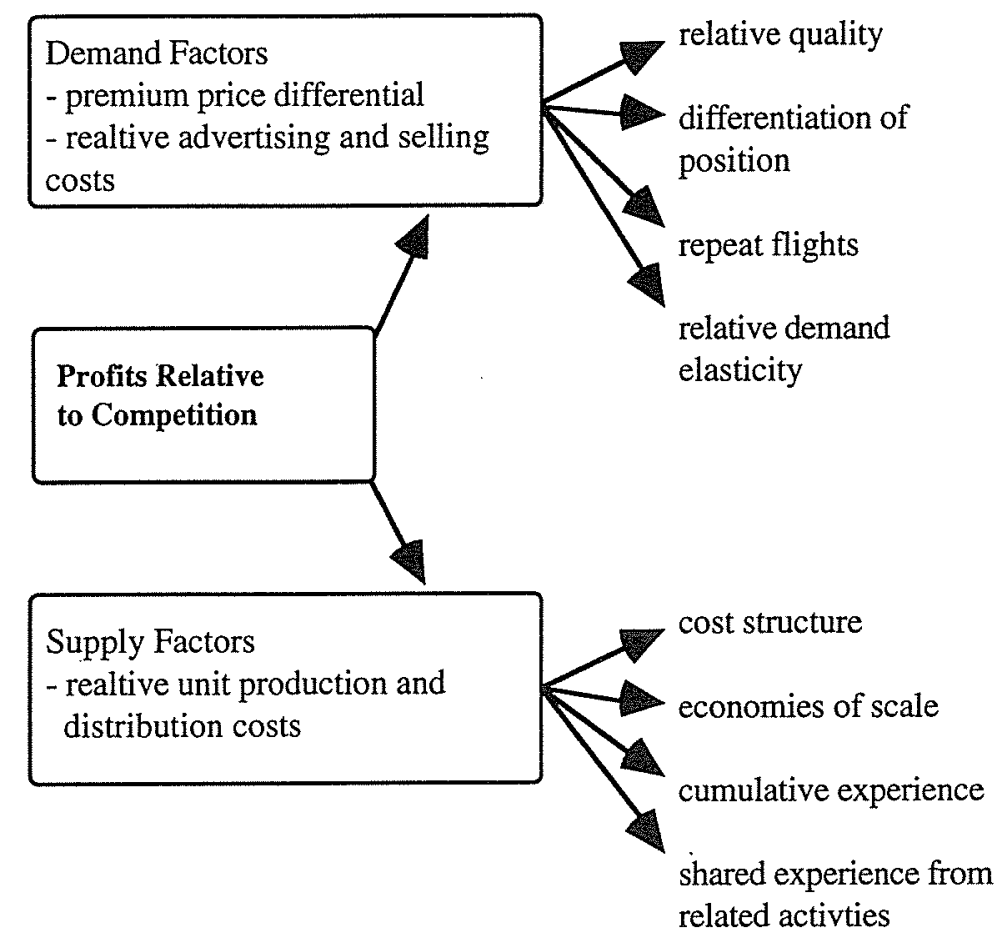

\section{Exhibit $4.2 \quad$ Sources of Profitability}

In addition there are strategies for harvesting, divesting or turning around a serious decline in productivity. However, these are extreme management strategies to either maximise short term returns, rapidly exit the industry or avoid a potential business failure. ${ }^{76}$

\section{Value Chains}

Beyond the price-service frequency distinctions which this paper has developed there is a broader concept of customer value. The demand side concept of relative value in use is the maximum amount a customer should be willing to pay for a firm's product assuming that he or she is fully aware of the firm's product and competitors' products. ${ }^{77}$ The relative value in use will differ from the purchase price of the reference product by the perceived savings in start-up and post purchase costs. 
For example, Exhibit 4.3 shows a customer value analysis estimated for usage situations of two similar products. We will examine a normal business class fare for a journey between, say, Sydney and London based on inflight service and dedicated check-in. One way to enhance a competitive edge in this market would be to offer frequent flyer points, reducing post purchase costs associated with additional flights on that airline. Start-up costs, which are related to search and information costs could be minimised through more effective promotion and availability of this fare.

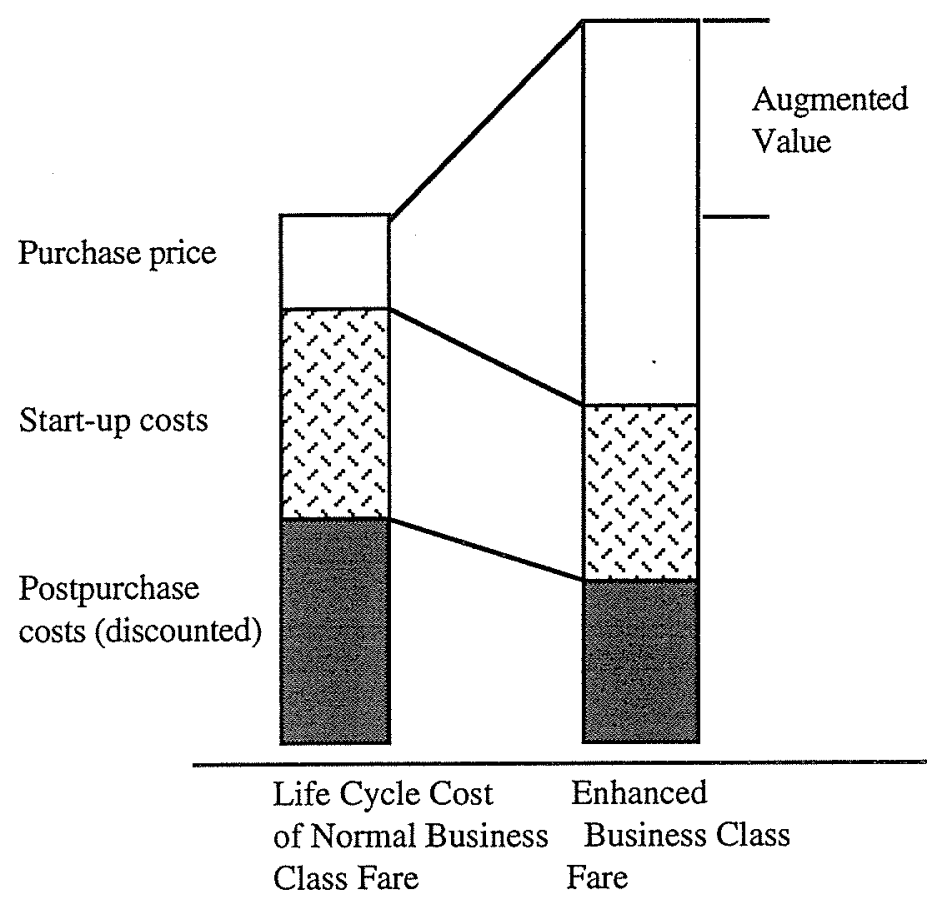

Exhibit 4.3 Enhancing Customer Value

Another way of reducing post purchase costs is by offering free flights to Europe at the end of the Sydney-London leg with the enhanced business class fare and a day's free car rental at the destination. Travellers will value these downstream services and this augments the value of the enhanced business class fare by the amount shown in the diagram. Note that the purchase price can be significantly increased as a result of incorporating these services in an integrated travel service.

There are a range of attributes which contribute to the enhancement of customer value in airline services. These include: usefulness, in terms of reducing effort to located additional services; security, which could be obtained, for example through 
dedicated check-ins, inflight cabin services and preferential hotel accommodation; and availability, an assurance that there is immediately provision of the service on demand.

This naturally is related to ways in which airlines can gain a competitive advantage through maximising the relative value in use of the services which they provide. Some of the opportunities which are available provide inducements for travellers to switch from one airline to another.

Design or technology changes in aircraft usually involve a trade-off between startup and operating costs. Newer aircraft are more expensive to purchase, however, they typically give lower per passenger costs making airlines more competitive on a flight by flight basis.

The addition of functional services to the core business of flying people from point $A$ to point $B$ can enhance the value of that service by helping the passenger to maximise the time available during their trip. This is of particular importance to business passengers.

Customer value can also be augmented by superior performance on intangibles such as inflight service, on time performance to airline schedules and access by customers to airport lounges, valet parking and other ground-side services.

The strategy of enhancing consumer value is a demand side strategy. Demand for a product is enhanced through a range of tactics. The alternative approach is to examine value from the supply side, the perspective of the firm.

Ageneric firm's value chain can be comepared with some representative technologies in an airline's value chain. Here will wil adapt some concepts from Michael Porter's Competitive Advantage: Creating and Sustaining Superior Performance. ${ }^{78}$ This can be used as a template to integrate actions which have profitability or market share implications to enable airline managers to evaluate their proposed business tactics within one consistent strategic framework.

An airline can radically alter its relative cost position by adopting a value chain that is significantly different from its competitors'. No-frill airlines such as People's

78 Porter (1985), p167 
Express and Southwest Airlines have adopted chains that differ markedly from trunk carriers. ${ }^{79}$ This is summarised in Exhibit 4.4.

\begin{tabular}{|c|c|c|c|c|c|c|}
\hline & $\begin{array}{l}\text { Ticket } \\
\text { Counter } \\
\text { Operations }\end{array}$ & $\begin{array}{l}\text { Gate } \\
\text { Operations }\end{array}$ & $\begin{array}{l}\text { Aircraft } \\
\text { Operations }\end{array}$ & $\begin{array}{l}\text { On-board } \\
\text { Service }\end{array}$ & $\begin{array}{l}\text { Baggage } \\
\text { Handling }\end{array}$ & $\begin{array}{l}\text { Ticket } \\
\text { Office }\end{array}$ \\
\hline $\begin{array}{l}\text { Trunk } \\
\text { Airlines }\end{array}$ & Full service & Full service & $\begin{array}{l}\text { Purchase } \\
\text { new } \\
\text { aircraft } \\
\text { Union } \\
\text { Pilots }\end{array}$ & Full service & $\begin{array}{l}\text { Free } \\
\text { baggage } \\
\text { checking }\end{array}$ & $\begin{array}{l}\text { Ticket } \\
\text { offices in } \\
\text { downtown } \\
\text { locations }\end{array}$ \\
\hline $\begin{array}{l}\text { No-Frill } \\
\text { Carriers }\end{array}$ & $\begin{array}{l}\text { Secondary } \\
\text { airports } \\
\text { and } \\
\text { terminals } \\
\text { No ticket } \\
\text { counter (or } \\
\text { check-in } \\
\text { only) } \\
\text { Purchase } \\
\text { tickets on } \\
\text { board the } \\
\text { aircraft or } \\
\text { from } \\
\text { machines } \\
\text { No interline } \\
\text { tickets } \\
\text { Few fare } \\
\text { options }\end{array}$ & $\begin{array}{l}\text { Secondary } \\
\text { airports } \\
\text { and } \\
\text { terminals } \\
\text { First come, } \\
\text { first served } \\
\text { seating } \\
\text { No ticketing } \\
\text { at gates }\end{array}$ & $\begin{array}{l}\text { Used aircraft } \\
\text { Non-union } \\
\text { pilots } \\
\text { Smaller } \\
\text { crews and } \\
\text { more } \\
\text { flying } \\
\text { hours per } \\
\text { day }\end{array}$ & $\begin{array}{l}\text { Nonunion } \\
\text { flight } \\
\text { attendants }\end{array}$ & $\begin{array}{l}\text { Provide } \\
\text { carry-on } \\
\text { space } \\
\text { Charged for } \\
\text { checked } \\
\text { baggage } \\
\text { No interline } \\
\text { baggage }\end{array}$ & None \\
\hline
\end{tabular}

Exhibit $4.4 \quad$ Alternative Value Chains in Airlines

An airline which is not the market leader needs an aggressive strategy to stay in the market. Related to some of the points raised in support of the positional advantage concept, there are three possible avenues of attack: 80

- Reconfiguration. An airline innovates the way it performs activities in the value chain or in the entire configuration of the chain.

- Redefinition. An airline redefines its competitive scope compared to the leader.

79 Porter (1985), pp 107-8

80 Porter (1985), p518 
- $\quad$ Pure spending. An airline buys market position through superior resources or greater willingness to invest, out of which competitive advantage grows.

These concepts may be expressed in terms of competitive scope and the configuration of the airline's value chain which are summarised in Exhibit 4.5.81 What this exhibit reveals is that the traditional concept of spending to acquire a competitive advantage, usually through acquiring market position or market share, is only one facet of the competitive strategic armoury which new entrants or market followers can use to try to gain market dominance or leadership. ${ }^{82}$

\section{CONFIGURATION OF THE VALUE CHAIN}

Same Chain As New Activities New Chain

Leader

\begin{tabular}{l|l|l|l|}
\multicolumn{2}{c}{$\begin{array}{l}\text { Same Chain As } \\
\text { Leader }\end{array}$} & \multicolumn{1}{c}{ New Activities } & \multicolumn{1}{c}{ New Chain } \\
\cline { 2 - 4 } $\begin{array}{l}\text { Same } \\
\text { as } \\
\text { Leader }\end{array}$ & $\begin{array}{l}\text { Pure } \\
\text { Spending }\end{array}$ & Reconfiguration & Reconfiguration \\
\cline { 2 - 4 } $\begin{array}{l}\text { Different } \\
\text { from } \\
\text { Leader }\end{array}$ & Redefinition & $\begin{array}{l}\text { Reconfiguration } \\
\text { and } \\
\text { Redefinition }\end{array}$ & $\begin{array}{l}\text { Reconfiguration } \\
\text { and } \\
\text { Redefinition }\end{array}$ \\
\hline
\end{tabular}

Exhibit 4.5 Avenues for Attacking Leaders

\section{Profit Impact of Marketing Strtaegies}

The key question this paper addresses is whether airline profitability is enhanced in the pursuit of market share.

The Strategic Planning Institute runs the Profit Impact of Marketing Strategy (PIMS) program which analyses data to determine what type of business strategy in what kind of competitive environment produces what profit results. ${ }^{83}$ The key

\footnotetext{
81 Porter (1985), p518

82 An interesting point to note here is that whilst Porter examines the concept of market leadership and how firms develop strategies to enhance market leadership, there is no linkage between market leadership and profitability. The most profitable airline in the US last financial year was not one of the market leaders such as Delta, United or American Airlines, but a regional carrier, Southwest Airlines. Over the last three years, Southwest Airlines has provided a compound annual return to shareholders of about 90 per cent (Lawrinsky (1993), p205).

83 Grieve Smith (1985), p89
} 
suggestion of this research is that a 10 percentage point improvement in market share was closely associated with a 5 percentage point improvement in profitability.

This analysis may not be relevant to the airline industry because the survey data focused on manufactured goods rather than on services. The industry sectors tended to be more stable, mature sectors whereas the aviation industry is a high growth, volatile industry. ${ }^{84}$

The experience curve phenomenon, which is related to the PIMS concept, was first published by the Boston Consulting Group (BCG) in 1968. The analysis was based on some 24 products. The result has been to identify a relationship between profitability and experience, or cumulative market share. ${ }^{85}$ The business portfolio matrix shown in Exhibit 4.6 has been used to summarise the results of the BCG's findings.

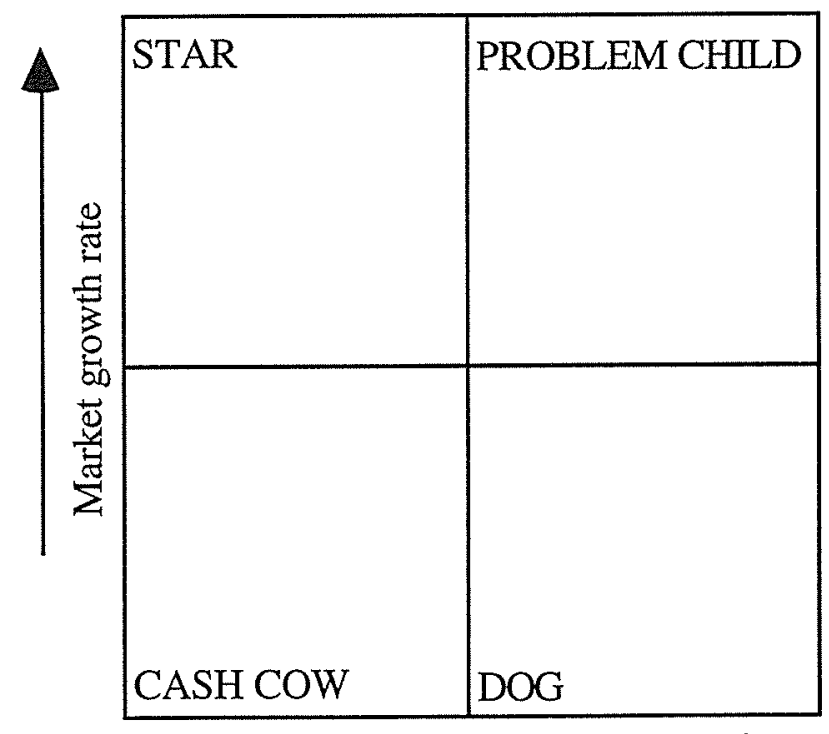

Market share relative to major competitor

Exhibit 4.6 The business portfolio matrix

84 Lawrinsky (1993), p204

85 Pearson (1985), pp24-5 From a limited sample of 24 products Boston Consulting Group concluded that prices follow the same pattern as costs if the industry is relatively stable and if cost is a function of accumulated experience, then profit is a function of market share. 
Whilst this portfolio analysis may not be suitable at an airline level, it can have some applicability for managing a portfolio of different routes.

For example, a star has a high cash generation and usage. The cashflow can either be positive or negative. A firm has to invest heavily to maintain market share with price competition only where necessary to hold market share. A classic example of this type of market is the Japan-Australia route which is characterised by high load factors and high yield passengers. ${ }^{86}$

A cash cow has low cash usage and high generation with a positive cash flow. The firm should ration new investment and maintain prices up to a level above which new marginal competitors would be attracted.

A problem child has a negative cashflow based on high usage and low generation. The firm can either raise market share or get out by raising prices. Essentially this is the situation faced by carriers operating on a number of trans-Pacific routes. ${ }^{87}$

A dog is a low cash usage and generation market in which the cashflow can either be positive or negative. The firm should manage for cash and withdraw.

Market share or experience is not necessarily a key to profitability. It tends not to be true in other than very high-growth industries because costs reductions as experience increases become very small and, in the real world, is often completely hidden by other factors. ${ }^{88}$ The Boston Consulting Group's 'experience curve' suggested that each time accumulated production of a product doubled, real unit costs declined by a percentage, characteristically in the range of 20 to 30 per cent. ${ }^{89}$ Where prices will not follow the same pattern as costs is when the relationships between competitors in an industry become increasingly unstable. This is the case in the aviation industry.

86 This route is a recognised cashcow for Qantas. High load factors indicate aircraft flying on the route at near passenger capacity based on aviation statistics (DOTAC (1993b),pp9-10) and fare category data collected through tourism research suggests a large number of Japanese passengers are paying full economy fares (BTR (1992), p39).

87 Notwithstanding the withdrawal of Continental Airlines, the remaining carriers operating services between Australia and the US are now in a situation where price competition has driven down yields on the route so the route is not lucrative, even though the United States is Australia's third largest source of tourists.

88 Pearson (1985), pp45-6

89 Grieve Smith (1985), p89 


\section{Chapter 5 An Empirical Examination of Profitability and Market Share}

In the preceding chapters the linkages between airline market share and profitability have, a priori, been shown to be tenuous at best. This chapter examines several models of behaviour of airlines and passengers to test from empirical data the weakness of this relationship.

A model of passenger demand is developed which is used in a counterfactual analysis, assuming a profitability-market share relationship. This rests on the key variables of price and frequency of service. A simple airline cost function is proposed and this framework is tested in a control market to show the interaction of these variables. A network trip generation model is then developed to show how aggregate base level demands are generated on a range of routes.

\section{A Demand Model for Air Services on a Route}

In order to determine the optimum strategy regarding market share which will enhance airline profitability, a demand model needs to be determined which will indicate travellers' responsiveness to changes in fares and service frequency. This is a critical element in the analysis of a relationship between profitability and market share and provides an explanation for how an airline's strategic actions impact on its market share and level of profitability.

Traditional economic concepts of demand examine a wide range of factors, such as the prices of all other goods, income, expectations, tastes and population. ${ }^{90,91}$ The

90 Waud and Hocking (1992), pp85-8 and Miller (1986), pp17-20. Miller also points out that population increases affect demand for different categories of goods and services.

91 Petersen and Lewis (1990), pp126-8 
initial model we will develop is a short-run demand model which assumes that income levels are constant. ${ }^{92}$ This also assists us in isolating key short-run factors such as price.

Following work undertaken by the Bureau of Transport and Communications Economics (BTCE 1990) we can develop a demand model which incorporates passenger responses to changes in service frequency and air fares.

The number of passengers in a particular scenario, Passengers, , can be given as:

$$
\text { Passengers }_{\mathrm{s}}=\text { Passengers }_{\mathrm{b}} *\left(\text { Fare }_{\mathrm{b}} \div \text { Fare }_{\mathrm{a}}\right)^{\partial}
$$

where Passengersb is the average level of demand in a twelve month period, Fare $b$ is the average fare on the route in a twelve month period, Fare ${ }_{\mathrm{a}}$ is the new qualityadjusted 'true price', and $\partial$ is the price elasticity of demand. What is implicit in equation (1) is that Passengers $b$ is the demand base.

Fare $_{\mathrm{a}}$ is calculated as follows:

$$
\text { Fare } \left._{a}=\text { Fare }_{\mathrm{s}} *(\text { Frequencyb } \div \text { Frequency })\right) f \div \partial
$$

where Fare $_{\mathrm{S}}$ is the fare level under the new scenario, Frequencyb is the average frequency of service on the route in a twelve month period, Frequencys is the new service frequency, and $f$ is the service frequency elasticity of demand.

This means that we have a demand model with the following form:

$$
\text { Passengers }_{S}=\text { Passengersb }^{*}\left(\text { Fare }_{b} \div \text { Fare }_{S} *\left(\text { Frequencyb }_{b} \div \text { Frequency }_{s}\right) f \div \partial\right) \partial
$$

In order to refine the analysis a specific route, Sydney-Melbourne, was selected. 93 The route accounts for about 20 per cent of all domestic Australian air travel and has a high proportion of business passengers. ${ }^{94}$ Using the approach outlined

92 Mitchell (1993) has recently estimated relationships between the level of economic activity, using concepts such as GDP per capita, and revenue passenger kilometres for a range of countries in the Asia-Pacific region to forecast inbound passenger numbers. However, this modelling approach focuses on aggregate demand relationships between countries over a number of years.

93 The type of analysis proposed in this paper is highly information intensive. To conduct a network-wide examination of this model would require far more data and not necessarily yield results which are different from an examination of one major route.

94 BTCE (1991b) 
above, base level parameters for this analysis were calculated. Between 2 May 1992 and 15 May 1993 an average of 27890 passengers were carried one way on the route each week. During this period an average of 316 weekly services carried these passengers. ${ }^{95}$ Air fare data is difficult to obtain, however, a telephone survey of major operators on the route indicates that the average one-way fare that passengers may pay is about $\$ 351$. This is a weighted average of first, business, economy and discount fares offered by the major airlines on the route.

The next step in the analysis was to determine the service elasticity of demand and the price elasticity of demand on this route. This problem is solved by examining two situations: where passenger numbers change solely due to changes in air fares or they change due to changes in service frequencies.

From data on passenger numbers and service frequencies we note that during the week ending 9 January 1993 there were about the same number of services between Sydney and Melbourne which carried 22985 passengers. Bookings for these flights would have been made just before the major airlines offered heavily discounted seats. If the average discount fare on the route was 50 per cent of the normal economy fare then the average fare paid by passengers would have risen from $\$ 351$ to $\$ 382$. This is expressed in equation (4) by substituting these values into equation (3).

In another situation we note that air fares have not varied during May 1993, however passenger numbers have changed and service frequency has changed as well. For example, in the week ending 15 May 1993, there were 307 services which carried a total of 26425 passengers. This is expressed in equation (5) by substituting these values into equation (3).

These two equations can then be used to solve for $f$ and $\partial$.

$$
\begin{aligned}
& 22985=27890 *(\$ 351 \div \$ 382 *(316 / 316) f \div \partial) \partial \\
& 26425=27890 *(\$ 351 \div \$ 351 *(316 \div 307) f \div \partial) \partial
\end{aligned}
$$

Dividing both equations by Passengers $\mathrm{b}=55781$ and rearranging terms gives:

95 DOTAC (1993a) 


$$
\begin{aligned}
22985 \div 27890 & =(\$ 351 \div \$ 382)^{\partial} \\
26425 \div 27890 & =((316 \div 307 f \div \partial) \partial
\end{aligned}
$$

Solving for $\partial$ and $f$ gives the following estimated values:

$$
\begin{gathered}
\partial=2.285 \\
f=-1.87
\end{gathered}
$$

The interpretation of $\partial$ and $f$ is as follows. A 1 per cent increase in fares will reduce passenger numbers by about 2.3 per cent. A 1 per cent reduction in service frequency will decrease passenger numbers by about 1.9 per cent.

\begin{tabular}{rccccc}
\hline Week & Services & $\begin{array}{c}\text { Actual } \\
\text { Passenger } \\
\text { Numbers }\end{array}$ & $\begin{array}{c}\text { Average } \\
\text { Fare }\end{array}$ & $\begin{array}{c}\text { Estimated } \\
\text { Passenger } \\
\text { Numbers }\end{array}$ & $\begin{array}{c}\text { Deviation from } \\
\text { Actual Passenger } \\
\text { Numbers }\end{array}$ \\
\hline 15-May-93 & 307 & 27558 & 351 & 26410 & $4 \%$ \\
8-May-93 & 301 & 26282 & 351 & 25453 & $3 \%$ \\
1-May-93 & 307 & 26425 & 351 & 26410 & $0 \%$ \\
10-Apr-93 & 306 & 30031 & 339 & 28421 & $5 \%$ \\
3-Apr-93 & 314 & 31129 & 339 & 29826 & $4 \%$ \\
27-Mar-93 & 312 & 31572 & 339 & 29384 & $7 \%$ \\
20-Mar-93 & 307 & 30328 & 339 & 28508 & $6 \%$ \\
13-Mar-93 & 334 & 28785 & 351 & 30833 & $7 \%$ \\
6-Mar-93 & 363 & 30446 & 382 & 29699 & $2 \%$ \\
27-Feb-93 & 372 & 31856 & 382 & 31171 & $2 \%$ \\
20-Feb-93 & 365 & 33381 & 382 & 30006 & $10 \%$ \\
13-Feb-93 & 363 & 30562 & 382 & 29775 & $3 \%$ \\
6-Feb-93 & 349 & 31711 & 382 & 27664 & $13 \%$ \\
30-Jan-93 & 346 & 32505 & 351 & 32940 & $1 \%$ \\
23-Jan-93 & 334 & 30334 & 351 & 30833 & $2 \%$ \\
16-Jan-93 & 326 & 26792 & 382 & 24353 & $9 \%$ \\
9-Jan-93 & 318 & 22958 & 382 & 23179 & $1 \%$ \\
2-Jan-93 & 308 & 21098 & 382 & 21899 & $4 \%$ \\
\hline
\end{tabular}

Exhibit 5.1 Comparison of Actual and Estimated Passenger Numbers

In order to check whether these figures represent a reasonable approximation of the price and service frequency elasticities of demand on the route in 1993 we have 
compared actual passenger data with the estimated passenger numbers derived from equation (3) and the elasticities which were calculated above. There is an average 5 per cent deviation in passenger numbers which is small enough to be acceptable for the purposes of this paper. Average air fares varied over the period shown in the Exhibit because of different discount fare offers which were assumed. Discount fares of 50 per cent off normal economy fares increase the average fare to $\$ 382$ and 70 per cent discounts reduce the average fare to $\$ 339$.

\section{Counterfactual Analysis - Conditions Establishing A Relationship Between Profit and Market Share}

In this section we will develop an analysis of a relationship between airline profitability and market share based on traffic generation assumptions developed in the previous section. A counterfactual analysis is used to outline this hypothesised relationship and then test whether or not empirical data provide support for this argument.

What we want to test is if profitability $(\mathrm{P})$ is some function of market share $(\mathrm{M})$. Conceptually this can be expressed as:

$$
\mathrm{P}=\mu(\mathrm{M})
$$

Behind this simple functional form lies a range of assumptions about how the market services this particular air route. For simplicity we assume at the outset a single route, ignoring the complexities of airline network scheduling and other transport logistic issues in order to focus on the fundamental nature of equation (10) which is the prime focus of this minor thesis. Profit is defined in the economic sense as a short-run phenomenon, assuming the capital stock used by airlines in the market is fixed. Miller (1985, p228) defines economic profit as the difference between total revenue and total costs. So we define profit $(\mathrm{P})$ as the difference between revenues $(R)$ from air fares paid by passengers and the cost $(C)$ of providing airline services which are used by those passengers. Which may be expressed as:

$$
\mathrm{P}=\mathrm{R}-\mathrm{C}
$$


The revenue and cost elements in the profit function above may be expressed as functions of passengers (PAX) carried by airline $\mathrm{i}$ as follows where $\varnothing$ and $\partial$ are per passenger revenues and costs:

$$
\mathrm{R}=\emptyset \mathrm{PAX}, \mathrm{C}=\partial \mathrm{PAX}
$$

Note that market share is simply the ratio of passengers (PAX) carried by a particular airline to the total number of passengers (TPAX) in the market. There are a range of measures which are used by the aviation industry to measure airline output and compare services offered by different airlines. Passenger kilometres measures the product of the number passengers carried by the distance they are flown. Revenue ton kilometres measures the total weight carried by airlines, where passengers numbers are converted into an average weight figure, including on board luggage, and unaccompanied freight is added to the total. This freight figure is then multiplied by the distances the freight is carried. In this example we are examining services on a particular route, so varying distances is not an issue, and the analysis excludes a discussion of freight.

$$
\mathrm{MS}=\mathrm{PAX} \div \mathrm{TPAX}
$$

This passenger quantity element in profitability and market share may be eliminated to assess the key values in the assumed relationship.

$$
(\varnothing \mathrm{PAX}-\partial \mathrm{PAX})=\mu(\mathrm{PAX} \div \mathrm{TPAX})
$$

rearranging gives

$$
\emptyset-\partial=\mu(\mathrm{PAX} \div \mathrm{TPAX}) \div \mathrm{PAX}
$$

If there is a relationship between market share and profitability, equation (15) suggests that as the total market increases in size per passenger profitability falls. This is analogous to diminishing marginal concepts used in economic literature. This is related to a diminishing marginal return concept and explains why profits on carrying additional passengers might decline in a situation of constant average cost.

However, the total size of the market is affected by a range of factors including the prices of air fares, the frequency of services, the range of inflight services, ease of 
check-in, alternative modes of transport, reasons for travel (for example, business, visiting friends and relatives, holiday). ${ }^{96}$ For this paper we will focus on airfares and frequency of service as the major determinants which have been identified in equation (3) above.

Therefore

$$
\text { TPAX }=\text { Passengers }
$$

The term $(\varnothing)$ in equation (12) is identical to the air fare offered by carrier $i$ which affects total market size (TPAX). We therefore have a situation where there are two forces impacting on profitability through a change in air fares.

Suppose that airline i decides to increase air fares. What impact would this have on the profitability of the airline? It is by no means clear that a rise in air fares would unambiguously increase profitability since an increase in FAREi would tend, under our assumptions to decrease the size of the market and possibly the number of passengers carried by airline $i$.

The connection between price and market share is established through a price substitution factor and a frequency-based market share substitution factor. ${ }^{97}$ The first is derived by adjusting the airline's share of capacity on the route for the deviation of its own fare from the route average fare. The second measure is based on the relative frequency contributed by the airline on the route.

\section{Price and frequency connections of profitability and market share}

The proportion of traffic carried by airline $\mathrm{i}\left(\right.$ Shareprop $\left._{i}\right)$ is therefore determined by the number of passengers on the route and airline i's share of that traffic. To calculate Sharepropi we need to define passenger responses to the relative fares and service frequencies it offers. Shareprop $i$ can be defined as

96 BTCE (1991b)

97 In this instance we explicitly assume that there is a relationship in order to test whether or not that relationship is valid. This is simply a pedagogical device. The alternative would be to assume that no relationship exists, however, this would be more difficult to model. 
Shareprop $_{i}=\left(1-\right.$ Freqprop $\left._{i}\right) *$ Nonfreqshare $_{i}+$ Freqprop $_{i} *$ Freqshare $_{i}(17)^{98}$

which states that airline i's share of traffic depends on the relative price (Nonfreqshare ${ }_{i}$ ) and service frequency (Freqshare ${ }_{i}$ ) weighted by the proportion of time sensitive passengers on the route (Freqpropi).

The introduction of an assumption about time sensitive travellers is an important part of the analysis because information on different customer categories in the market will determine an airline's strategic responses to the particular situation of a market. For example, business travellers tend to be relatively insensitive to price and sensitive to service frequency. For a market with a high proportion of business traffic an airline could increase its profitability by placing more services on the route rather than offering fare discounts. This is certainly the case for our test market, Sydney-Melbourne.

These terms in equation (17) may be further decomposed into equations (18) and (19)

$$
\text { Nonfreqshare }_{i}=\left(\mathrm{K}_{\mathrm{i}}^{*}\left(\text { Fare }_{\mathrm{i}} \div \text { Fare }_{\mathrm{a}}\right)^{\pi}\right) \div\left(\sum \mathrm{K}_{\mathrm{j}}^{*}\left(\text { Fare }_{\mathrm{j}} \div \text { Fare }_{\mathrm{a}}\right)^{\pi}\right)
$$

where $\mathrm{K}_{\mathrm{i}}$ is the number of seats airline $\mathrm{i}$ offers on the route and $\sum \mathrm{K}_{\mathrm{j}} *\left(\right.$ Fare $_{\mathrm{a}} *$ Fare $\left._{j}\right)^{\pi}$ is the sum of the products of all airlines' capacities and fares raised to a price substitution factor $(\pi)$. We have adopted a price substitution factor as a mechanism for identifying an airline's market share on the basis of a price differential. 99 A price substitution value of 6.0 implies for two identical airlines, if one charged a fare 10 per cent below the other it would increase its price-sensitive traffic by 30 per cent (an increase in its price sensitive market share from 50 per cent to 65 per cent). Since relative price differences were applied to capacity based market shares, a given relative price cut would attracted a smaller amount of traffic for an airline which had a smaller initial market share.

98

BTCE (1990)

99 BTCE (1990). Competition on fares is strongly related to the industry structure within which airlines operate. For example, in BTCE (1991b) it was shown that structural changes in the Australian aviation industry arising from domestic deregulation have increased air fare discounting. Cain and Harbison (1993), pp156-7, show that following deregulation in the US and Canada, the proportion of passengers flying on discounted tickets increased significantly. There has been increasing price sensitivity in markets to major US hubs and faster increases in air fares to short haul routes compared to long haul routes. Air fares have become increasingly complex. Between 1982 and 1987 fare changes in the US market have increased from 4.6 million to just over 49 million. 
Service quality on a route is the non price factor through which airlines have competed for patronage. Consumers' perceptions of service quality depend on their priorities ${ }^{100}$. It may be the case that business travellers place a high value on performance to schedule or airport lounges whereas leisure travellers may be ready to accept lower service quality for lower fares. The historical perception of business travellers had been that travel flexibility and other service elements were more important than price compared to non-business travellers. ${ }^{101}$ This has changed however as deregulation of domestic aviation ushered in discounted fares for business class travellers and premium class international airline yields have fallen.

The concept of service quality refers to the quantities of the characteristics that are embodied in a service and which directly interact with the utility functions of the consumers of that service. 102 In viewing a service as a bundle of characteristics, these factors may be aggregated into an aspect of service quality. ${ }^{103}$ There are a range of service qualities which are applicable to aviation. These include: safety, accessibility, frequency, non-stop service, on-time performance, airport services and facilities, and on-board comfort and service. A major problem has been how these qualitative factors are measured. Several criteria for the construction of service performance indicators are: coverage of key aspects, availability of data, consistency of data over time, protection of commercial confidentiality, promotion of incentives. 104

A summary of service quality changes which have been identified is shown in the exhibit below. 105

As frequency of service increases, service quality increases, ceteris paribus, because there is a wider range of service available for consumers and a greater probability of booking a flight at short notice if flight frequency increases the availability of seats. ${ }^{106}$ Service frequency is the main indicator of improvements in service quality used in this paper.

\footnotetext{
100 BTCE (1992b)

101 BTCE (1991b), p37

102 BTCE (1992b), p9. The BTCE's work in this area follows a framework originally developed by Lancaster in 1966 on a new approach to consumer theory which has greater applicability for service industries where the service product is heterogeneous.

103 Lancaster (1971), p6

104 BTCE (1992a)

105 BTCE (1992b), p37

106 BTCE (1992b), p19
} 


\begin{tabular}{lcc}
\hline Aspect of quality & $\begin{array}{c}\text { Assessment } \\
\text { Constant }\end{array}$ & Improved \\
\hline Safety & $*$ & $*$ \\
Accessibility & & $*$ \\
Frequency & & $*$ \\
Non-stop service & $*$ & \\
On-time performance & $*$ & \\
Airport services and facilities & & \\
On-board comfort and service & & \\
\hline
\end{tabular}

\section{Exhibit 5.2 Assessment of Changes in Service Quality}

A service frequency substitution factor $(S)$ has been adapted to explain the responsiveness in passenger demand arsing from changes in service frequency. ${ }^{107}$ A service frequency substitution factor value of 1.25 implies that if one airline increased its relative frequency of service, that airline would increase its market share of traffic in an enlarged market. For example, suppose an airline raised its frequencies from 50 per cent to 60 per cent of flights on a route, its share of time sensitive traffic would increase from 50 per cent to 62 per cent. If it increased its frequencies to 80 per cent, its market share would go to 85 per cent. This is used to calculate the share of traffic generated by time sensitive travellers as shown in equation (19) below.

$$
\text { Freqshare }_{i}=\text { Freqadji }_{i} S \div \sum \text { Freqadjj }_{j} S
$$

How is this linked to actual passenger numbers carried by airline i? Equation (17) is equivalent to equation (13) above. This may be expressed in the following way:

$$
\text { Shareprop }_{i}=\mathrm{PAX} \div \mathrm{TPAX}
$$

In order to test the validity of these assumptions we check the estimated market shares obtained by equation (17) against simulated data. The exhibit below shows market shares for airline $i$ under a range of different fares and service frequencies based on the assumption that 50 per cent of travellers on the route are time sensitive passengers. For this analysis we have assumed that one other airline is operating 
on the route and we have set the initial fare level at $\$ 100$, service frequency at 1000 flights one way each week and each airline's capacity at 10000 seats.

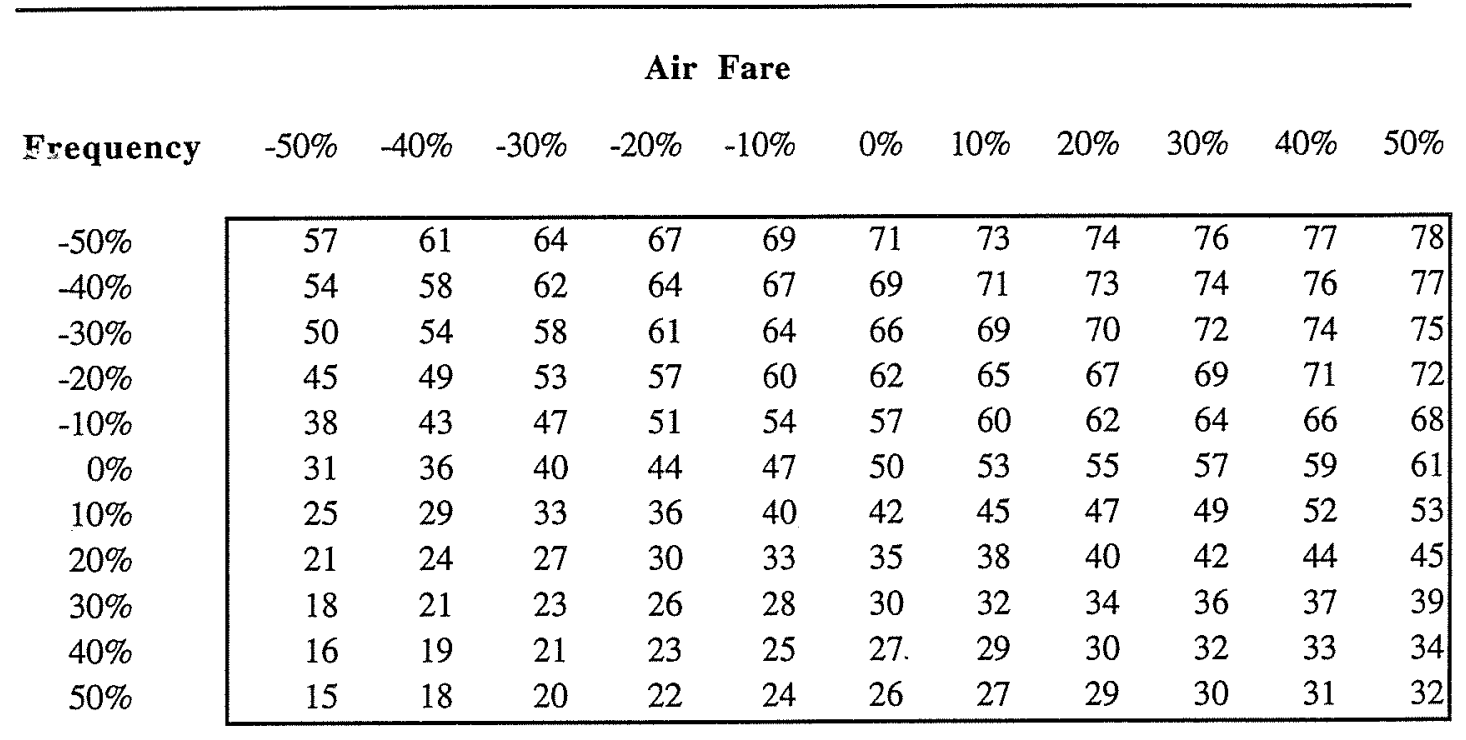

Exhibit 5.3 Market Share-Relative Air Fare and Frequency Impacts

An important point to note about the above analysis is that service frequency indirectly affects the response of passengers to fares because passengers' fare responses are weighted by the relative capacity each airline puts on the route. This means that as service frequency increases a given fare reduction will attract a larger market share for the airline. For this analysis we assume that the airline in question increases its frequency by using the same type of aircraft. So what does the pricefrequency market share surface look like using the model developed above? The exhibit below illustrates this. 


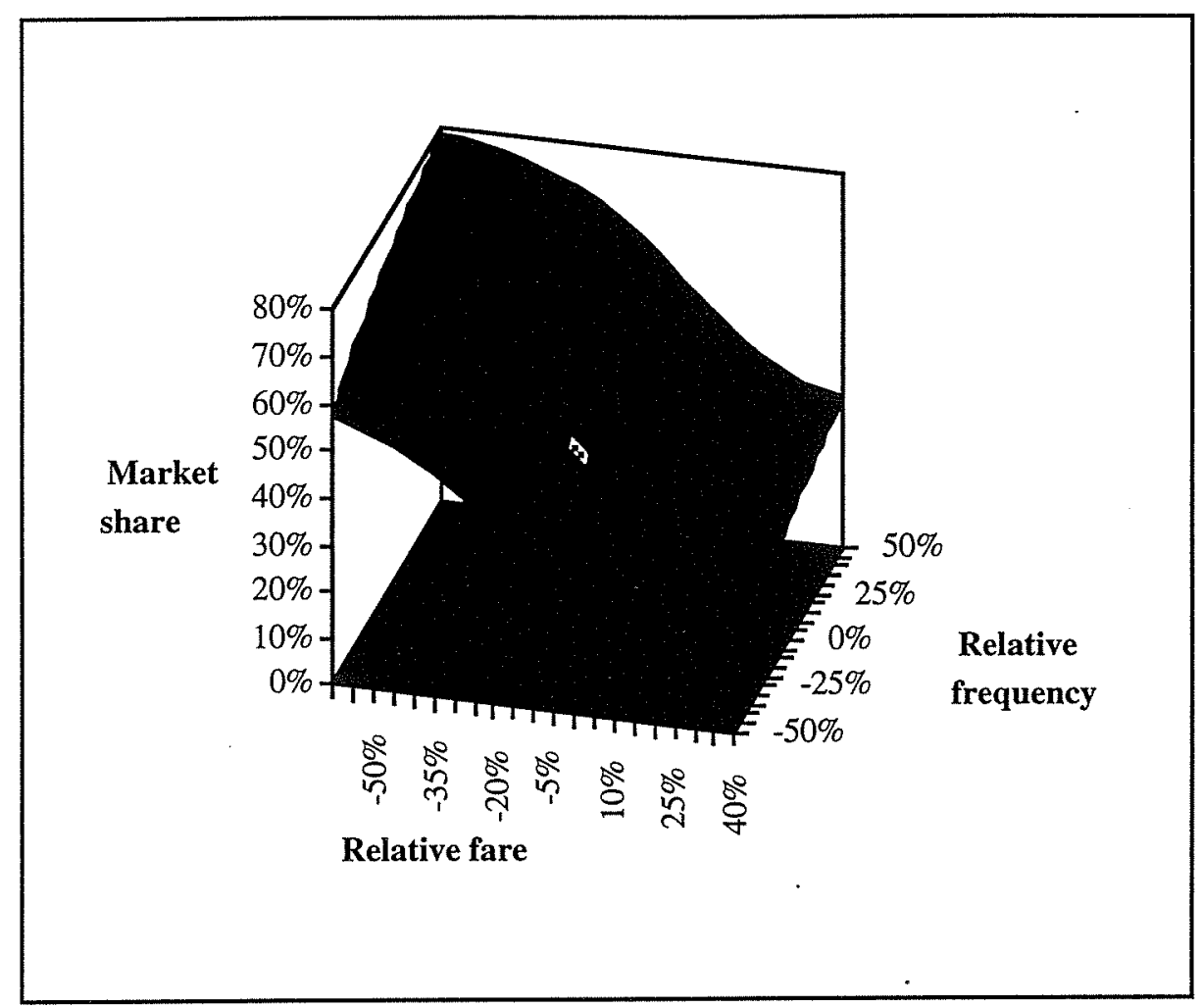

Exhibit 5.4

The Price-Frequency Market Share Surface

Defining a cost function for air services

Economies of scale and scope have affect an airline's cost structure. 108 Economies of aircraft size arise because large aircraft use carry more passengers without proportionate increases in fuel use, crew size or terminal costs. There are also economies of density arising from additional passenger numbers and higher load factors. Further economies are available through operating a larger fleet of aircraft as training costs, maintenance and repair costs, ground, station and handling costs are spread over a larger number of services.

If the number of passengers increases by 10 per cent, holding the route structure constant, costs increase by only 8 per cent. 109 What is the impact on a per passenger basis? Running through this proposition algebraically we can state that

108 According to Street, Smith and Spence (1993), p169, these economies are well within the reach of small operators. Economies of network density are, however, are one supply-side factor similar to a size economy which can affect the number of competitors in the market. BTCE (1991b), p19-20 109 Caves, Christensen and Tretheway (1984) 


$$
\mathrm{P}_{1}=\mathrm{P}_{0} *(1+10 \%)
$$

and

$$
\mathrm{C}_{1}=\mathrm{C}_{0} *(1+8 \%)
$$

where $P_{1}, P_{0}, C_{1}$ and $C_{0}$ are the initial and new passenger numbers and costs respectively.

Per passenger costs, $\mathrm{C}_{\mathrm{p} 0}$ and $\mathrm{C}_{\mathrm{p} 1}$, are therefore

$$
\begin{aligned}
& \mathrm{C}_{\mathrm{p} 0}=\mathrm{C}_{0} \div \mathrm{P}_{0} \\
& \mathrm{C}_{\mathrm{p} 1}=\mathrm{C}_{1} \div \mathrm{P}_{1}
\end{aligned}
$$

Substituting for $\mathrm{C}_{1}$ and $\mathrm{P}_{1}$ and we get

$$
\begin{gathered}
\left.\mathrm{C}_{\mathrm{p} 1}=\left(\mathrm{C}_{0} \div \mathrm{P}_{0}\right) *((1+8 \%)) \div(1+10 \%)\right) \\
\mathrm{C}_{\mathrm{p} 1}=\left(\mathrm{C}_{0} \div \mathrm{P}_{0}\right) * .9818
\end{gathered}
$$

Since we know that $\mathrm{C}_{0} \div \mathrm{P}_{0}$ is $\mathrm{C}_{\mathrm{p} 0}$ we can say that per passenger costs fall by about 1.8 per cent every time there is a 10 per cent increase in passenger numbers.

We now have the essential elements to complete the analysis of profitability and market share.

\section{Competitition within the Model}

Given the theoretical construction which has been developed above we can now proceed to model competitive interactions between carriers within this model framework. We look at a market structure and posit some behavioural responses by carriers.

\section{Hypothetical Market Z}

Suppose that we have two identical airlines, Carrier $\mathrm{X}$ and Carrier $\mathrm{Y}$, providing services on route $Z$. Given the same level of fares, quality of service, aircraft size 
and ground and station costs it would be reasonable to assume that the market is divided equally between these two carriers. ${ }^{110}$ The starting point for this analysis assumes that each airline has the following characteristics:

$$
\begin{array}{r}
\text { Initial fare }-\$ 100 \\
\text { Airline passengers } \quad-100000 \\
\text { Airline services } \quad-100 \text { flights. }
\end{array}
$$

Time sensitive passengers on each flight - $50 \%$

We will examine two cases which illuminate the profitability-market share choice in a static framework. Case $\mathrm{A}$ is where Carrier X reduces its fare by 20 per cent. There are three scenarios within Case A: (A1) Carrier $Y$ has no response, (A2) Carrier $Y$ matches the fare cut, or (A3) Carrier Y increases service frequency to generate additional passengers.

Case $B$ is where Carrier $X$ increases service frequencies by 10 per cent. There are three scenarios within Case B: (B1) Carrier Y has no response, (B2) Carrier Y matches the service frequency increase, or (B3) Carrier Y reduces fares to generate additional passengers.

The overall number of passengers in the market is estimated using the equations which were derived in the sections above. The exhibit below summarises the calculations which were used to generate profit and market share results for these six scenarios.

The first thing to note is airline profitability is affected by the initial starting point from which a proposed fare reduction of service frequency is proposed. We initially set profit at 20 per cent of revenues and in Case A1 this led to a reduction in profitability of 48 per cent for the carrier introducing the fare reduction. This is because Carrier $\mathrm{X}$ is earning 20 per cent less in revenue from its existing passengers and the marginal savings it is making by carrying additional passengers are not enough to offset the revenue reduction arising from its fare discounting.

110 Hotelling's principle of minimum product differentiation also reinforces the concept of equal market share given this situation as described in Tisdell (1986), p263 
The profitability of Carrier $\mathrm{Y}$ is solely affected by its reduction in market share. This model predicts that all additional passengers generated by the fare reduction are carried by Carrier $\mathrm{X}$ and a number of existing passengers carried by Carrier $\mathrm{Y}$ switch to Carrier X.

\begin{tabular}{|c|c|c|c|c|c|c|c|c|c|c|c|}
\hline \multirow[t]{2}{*}{$\begin{array}{l}\text { Relative } \\
\text { Fare }\end{array}$} & \multicolumn{11}{|c|}{ Relative Frequency } \\
\hline & $-50 \%$ & $40 \%$ & $30 \%$ & $-20 \%$ & $10 \%$ & $\overline{0 \%}$ & $10 \%$ & $20 \%$ & $30 \%$ & $40 \%$ & $\overline{50 \%}$ \\
\hline$-50 \%$ & $57 \%$ & $61 \%$ & $64 \%$ & $67 \%$ & $69 \%$ & $71 \%$ & $73 \%$ & $74 \%$ & $76 \%$ & $77 \%$ & $78 \%$ \\
\hline$-40 \%$ & $54 \%$ & $58 \%$ & $62 \%$ & $64 \%$ & $67 \%$ & $69 \%$ & $71 \%$ & $73 \%$ & $74 \%$ & $76 \%$ & $77 \%$ \\
\hline$-30 \%$ & $50 \%$ & $54 \%$ & $58 \%$ & $61 \%$ & $64 \%$ & $66 \%$ & & 7 & $72 \%$ & $\%$ & 75 \\
\hline$-20 \%$ & $45 \%$ & $49 \%$ & $53 \%$ & $57 \%$ & $60 \%$ & $62 \%$ & $65 \%$ & $67 \%$ & $69 \%$ & $71 \%$ & $72 \%$ \\
\hline$-10 \%$ & $38 \%$ & $43 \%$ & $47 \%$ & $51 \%$ & $54 \%$ & $57 \%$ & $60 \%$ & $62 \%$ & $64 \%$ & $\%$ & $68 \%$ \\
\hline $0 \%$ & $31 \%$ & $36 \%$ & $40 \%$ & $44 \%$ & $47 \%$ & $50 \%$ & $53 \%$ & $55 \%$ & $57 \%$ & $59 \%$ & $61 \%$ \\
\hline $10 \%$ & $25 \%$ & $29 \%$ & $33 \%$ & $36 \%$ & $40 \%$ & $42 \%$ & $45 \%$ & $47 \%$ & $49 \%$ & $52 \%$ & $53 \%$ \\
\hline $20 \%$ & $21 \%$ & 24 & $27 \%$ & $30 \%$ & $33 \%$ & $35 \%$ & $38 \%$ & $40 \%$ & $42 \%$ & $44 \%$ & $45 \%$ \\
\hline $30 \%$ & $18 \%$ & $21 \%$ & $23 \%$ & $26 \%$ & $28 \%$ & $30 \%$ & $32 \%$ & $34 \%$ & $36 \%$ & $37 \%$ & $39 \%$ \\
\hline $40 \%$ & $16 \%$ & $19 \%$ & $21 \%$ & $23 \%$ & $25 \%$ & $27 \%$ & $29 \%$ & $30 \%$ & $32 \%$ & $33 \%$ & $34 \%$ \\
\hline $50 \%$ & $15 \%$ & $18 \%$ & $20 \%$ & $22 \%$ & $24 \%$ & $26 \%$ & $27 \%$ & $29 \%$ & $30 \%$ & $31 \%$ & $32 \%$ \\
\hline
\end{tabular}

Exhibit 5.5 Frequency-Fare Combinations of Market Share

There is a point where fare reductions by Carrier $\mathrm{X}$ do not reduce the profitability of Carrier $\mathrm{X}$ but this is related to the cost of providing flights. This is a situation where costs initially are approximately 62 per cent of revenue. The model exhibits a razor edge characteristic in that a relatively small percentage change in fares can generate significant differences in profits. For example, if the fare reduction was only 10 per cent then in Case A1 the profitability of Carrier X increases by about 36 per cent.

In Case A2, the overall market is larger because both airlines are offering fare cuts which stimulate the market. By both cutting fares and carrying more passengers, in this case both airlines make a loss. This is again related to the starting point from which these discounts are offered and the profit situation of the carriers under these circumstances.

Case A3 examines the result arising from Carrier $Y$ matching market share through offering service frequencies to offset Carrier X's fare cut. The market is significantly stimulated in this situation because Carrier $Y$ has to offer a large number of additional flights. The profitability of Carrier $\mathrm{Y}$ is enhanced however, 
because the additional passengers it carries are being carried at the original fare, whereas Carrier X, whilst still more profitable, cannot match Carrier Y's profitability because it is carrying the same number of passengers on a discounted fare.

When Carrier X increases its frequency of service by 10 per cent in Case B1 we cobserve under this model a 39 per cent increase in profit because of several factors. Carrier X stimulates the market attracts proportionately more new passengers than Carrier Y. Carrier Y, however, still experiences an increase in passenger numbers using its services. Since we have assumed that as passenger numbers increase, per-passenger costs fall, profitability increases more than proportionately with the increase in passenger numbers for both airlines but Carrier X gets the major share of profits.

In Case B2, with a matching increase in capacity by Carrier Y, both carriers' profits are enhanced compared to Case B1.

Case B3, where Carrier $\mathrm{Y}$ offers a fare cut to equalise the market share Carrier $\mathrm{X}$ obtained through its increase in flights, Carrier Y still has an increase in profits, although it is a lot smaller because its per passenger yield is reduced due to the fare cut. Carrier X does not earn as large a profit in this case as in Case B2 because the overall market has not grown by as much.

The conclusions which we can draw from this analysis are that small reductions in fares can increase airline profitability because the proportionate increase in passengers carried by an airline more than offsets the reduction in revenue per passenger. Larger cuts in air fares tend to reduce airline profitability in spite of increasing market share. Service frequency increases tend to increase the profitability of airlines because we have assumed economies of scale in the provision of seats which reduces per seat costs while per passenger yields remain the same.

Given the assumptions used in the model, an increase in frequency has a proportionately greater effect than the same percentage reduction in air fares, all other things being equal. This is why so many airline choose to compete on frequency of service rather than price and when price is a critical factor in a market price competition tends to be excessively volatile. 


\section{A Simple Network Model of Trip Generation}

How is the level of demand for each route determined? The interaction of passenger loads on different routes of an airline's network of services is critical to its aggregate profit performance. Spatial models of airline passenger demand for transport services are closely related to the theory of location demand. ${ }^{111}$ In this section we will introduce a rudimentary gravity model which can be used to determine demand levels on a network of routes. ${ }^{112}$

The number of passengers using a route is the product of some measure of traffic generation at either end of the route weighted by some impedance. This is analogous to the measure used in physics to calculate gravitational attraction between to masses. The physics formula is

$$
F=k M_{1} M_{2} / d^{2}
$$

where $F$ is force, measured is Newtons, $k$ is a constant, $M_{1}$ is the mass of the first object, $\mathrm{M}_{2}$ is the mass of the second object, and $\mathrm{d}^{2}$ is the distance squared.

Similarly we can posit a model where trip generation has a similar functional form.

$$
\mathrm{P}=\partial \mathrm{O}_{1} \mathrm{O}_{2} / \mathrm{i}^{2}
$$

where $\mathrm{P}$ is the number of passengers using the route, $\partial$ is a constant, $\mathrm{O}_{1}$ is a traffic generation factor at point $1, \mathrm{O}_{2}$ is a traffic generation factor at point 2 , and $\mathrm{i}^{2}$ is some measure of impedance.

In order to test this theory we can posit that $\mathrm{O}_{1}$ and $\mathrm{O}_{2}$ are measures of population at either end of the route and $i^{2}$ is simply the distance between $O_{1}$ and $\mathrm{O}_{2}$ squared, which can be a proxy for the costs of providing services.

111 Petersen and Lewis (1990), pp581-2, show that there is a tendency for firms to locate in a single area in order to cater for a geographically dispersed market. In terms of spatial airline passenger demand models, passenger demand has a similar distance dimension that affects the aggregate level of service offered on a route.

112 Doganis (1966) showed how the gravity model could be used to simulate passenger demand for travel between nodes in an airline network. 
Suppose that we want to examine air services in a hypothetical network which is shown below.

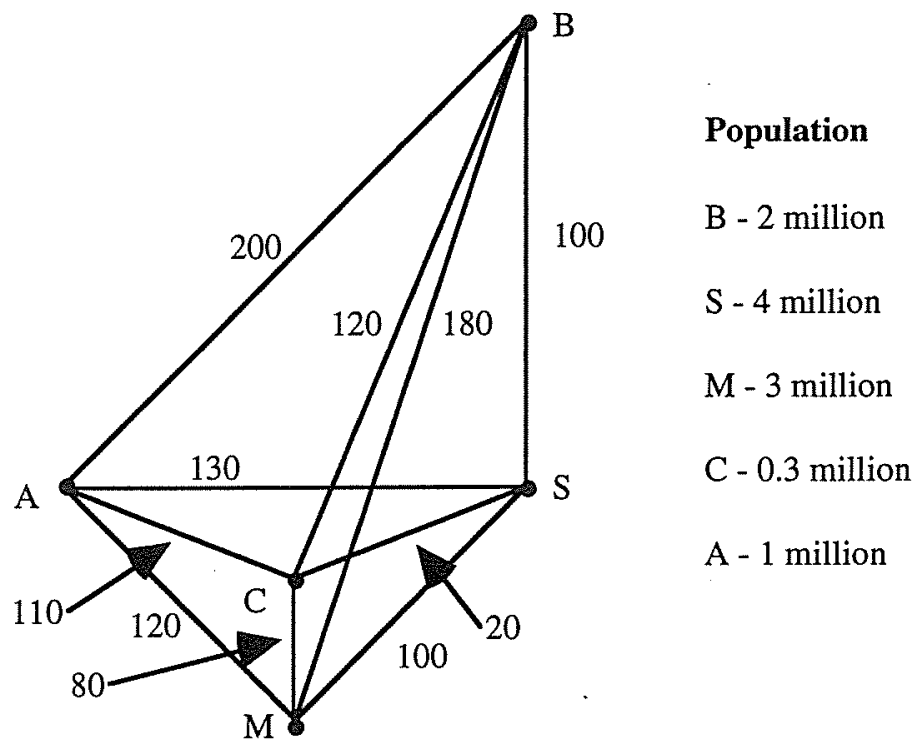

\section{Exhibit 5.6 Hypothetical route network}

Using the equation mentioned above it is possible to generate base level passenger demands between each origin destination pair in the exhibit. The term $\mathrm{k}$ is simply a logistic factor which is used to calibrate the model. In this instance $\mathrm{k}$ has bee set equal to the value $10^{-4}$. The results are summarised in the following exhibit.

\begin{tabular}{cccc}
\hline City pair & $O_{1} O_{2}$ & $d$ & Passengers \\
\hline BS & 8.0 & 100 & 80000 \\
BC & 0.6 & 120 & 4160 \\
BM & 6.0 & 180 & 18518 \\
BA & 2.0 & 200 & 5000 \\
SC & 1.2 & 20 & 300000 \\
SM & 12.0 & 100 & 120000 \\
SA & 4.0 & 130 & 23670 \\
CM & 0.9 & 80 & 14000 \\
CA & 0.3 & 110 & 2480 \\
MA & 3.0 & 120 & 20830 \\
\hline
\end{tabular}

\section{Exhibit 5.7 Gravity Model Passenger Generation}


There are two main relationships which can be used to compare different city pairs. For example, the distances between city pairs BS and SM are the same but the population of $\mathrm{M}$ is 50 per cent larger than $\mathrm{B}$. This is reflected in the traffic in the SM corridor being 50 per cent larger than BS. For the city pair BS, if the distance between B and S was halved then traffic in the corridor would be 320000 , four times the number in the exhibit.

The importance of using this model is to establish base level demands for each route.

When we run actual data through this model we can gain some insights into how airlines schedule services between city pairs within a network. Suppose the network we identified above was actually part of the domestic routes offered by Ansett and Qantas. This can be represented in the exhibit below.

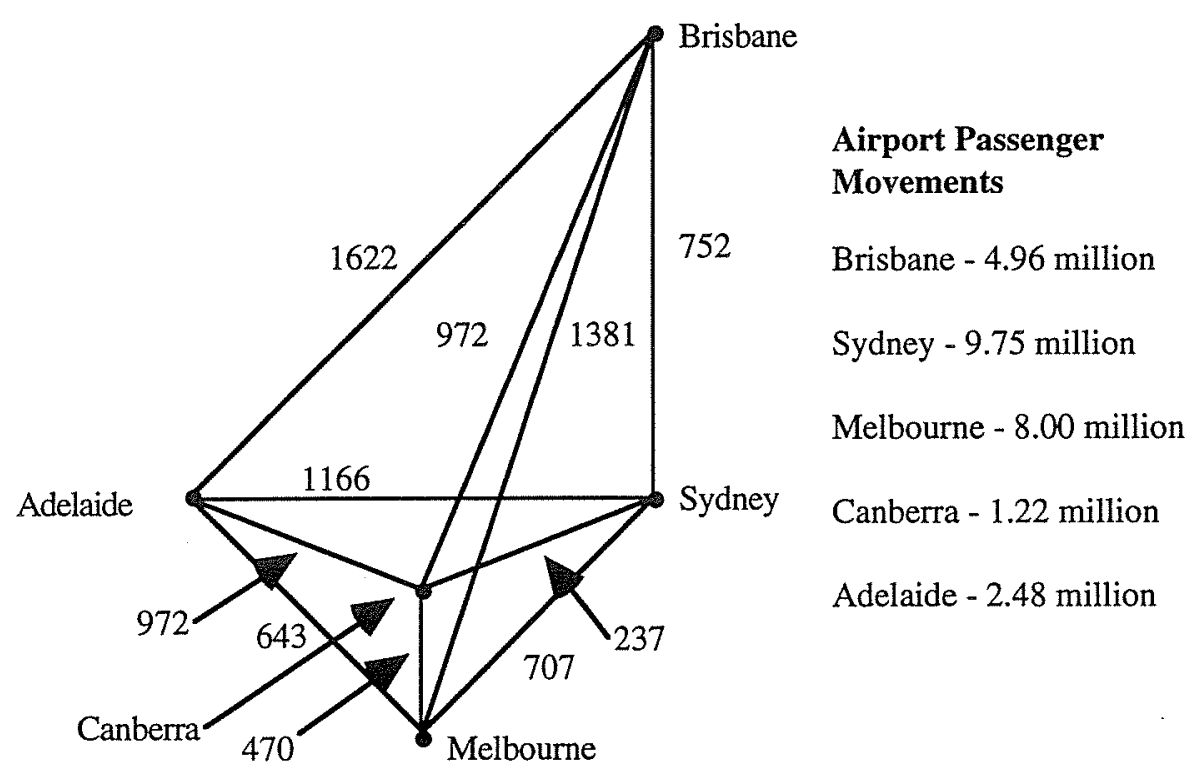

Exhibit $5.8 \quad$ Route Network: South-east Australia

Instead of using population data to determine trip generation between city pairs we use a more precise data set, annual passenger movements at domestic airport terminals. We also refine the model slightly in regard to the use of distance as a variable. In this example we will introduce a distance adjustment factor to account for some journeys which can also be undertaken by car, bus or rail. Estimated traffic on the network is shown in the exhibit below. 


\begin{tabular}{|c|c|c|c|c|c|c|}
\hline & Adelaide & Brisbane & Canberra & Melbourne & Sydney & Average \\
\hline Passenger & 2479187 & 4955234 & 1220155 & 7995933 & 9749127 & \\
\hline \multicolumn{7}{|l|}{ Movements } \\
\hline \multicolumn{7}{|c|}{$(0102)^{\wedge} 2 / 10^{\wedge} 12$} \\
\hline Adelaide & 6.146 & 12.285 & 3.025 & 19.823 & 24.170 & \\
\hline Brisbane & 12.285 & 24.554 & 6.046 & 39.622 & 48.309 & \\
\hline Canberra & 3.025 & 6.046 & 1.489 & 9.756 & 11.895 & \\
\hline Melbourne & 19.823 & 39.622 & 9.756 & 63.935 & 77.953 & \\
\hline Sydney & 24.170 & 48.309 & 11.895 & 77.953 & 95.045 & 5.029 \\
\hline \multicolumn{7}{|l|}{ Distance } \\
\hline Adelaide & 0 & 1622 & 972 & 643 & 1166 & \\
\hline Brisbane & 1622 & 0 & 956 & 1381 & 752 & \\
\hline Canberra & 972 & 956 & 0 & 470 & 237 & \\
\hline Melbourne & 643 & 1381 & 470 & 0 & 707 & \\
\hline Sydney & 1166 & 752 & 237 & 707 & 0 & 891 \\
\hline \multicolumn{7}{|l|}{$\begin{array}{l}\text { Distance } \\
\text { adjustment } \\
\text { ratio }\end{array}$} \\
\hline Adelaide & 0 & 1.82 & 1.09 & 0.72 & 1.31 & \\
\hline Brisbane & 1.82 & 0 & 1.07 & 1.55 & 0.84 & \\
\hline Canberra & 1.09 . & 1.07 & 0 & 0.53 & 0.27 & \\
\hline Melbourne & 0.72 & 1.55 & 0.53 & 0 & 0.79 & \\
\hline Sydney & 1.31 & 0.84 & 0.27 & 0.79 & 0 & 1.00 \\
\hline \multicolumn{7}{|c|}{ (O1O2/Distance 2$)$} \\
\hline Adelaide & 0 & 8504326 & 3494422 & 34616629 & 23275219 & \\
\hline Brisbane & 8504326 & 0 & 7101312 & 32214912 & 72132231 & \\
\hline Canberra & 3494422 & 7101312 & 0 & 23307924 & 56357237 & \\
\hline Melbourne & 34616629 & 32214912 & 23307924 & 0 & 123803456 & \\
\hline Sydney & 23275219 & 72132231 & 56357237 & 123803456 & 0 & 8480767 \\
\hline Total & 384807668 & $\mathrm{k}$ & & 2219.4557 & & \\
\hline \multicolumn{7}{|c|}{ Traffic on the network } \\
\hline Adelaide & 0 & 3832 & 1574 & 15597 & 10487 & \\
\hline Brisbane & 3832 & 0 & 3200 & 14515 & 32500 & \\
\hline Canberra & 1574 & 3200 & 0 & 10502 & 25392 & \\
\hline Melbourne & 15597 & 14515 & 10502 & 0 & 55781 & \\
\hline Sydney & 10487 & 32500 & 25392 & 55781 & 0 & \\
\hline \multicolumn{7}{|c|}{ Share of all traffic in network } \\
\hline Adelaide & $0 \%$ & $2 \%$ & $1 \%$ & $9 \%$ & $6 \%$ & \\
\hline Brisbane & $2 \%$ & $0 \%$ & $2 \%$ & $8 \%$ & $19 \%$ & \\
\hline Canberra & $1 \%$ & $2 \%$ & $0 \%$ & $6 \%$ & $15 \%$ & \\
\hline Melbourne & $9 \%$ & $8 \%$ & $6 \%$ & $0 \%$ & $32 \%$ & \\
\hline Sydney & $6 \%$ & $19 \%$ & $15 \%$ & $32 \%$ & $0 \%$ & $10 \%$ \\
\hline Total & $100 \%$ & & & & & \\
\hline
\end{tabular}

Exhibit $5.9 \quad$ Network Traffic in the Model-Empirical Data 
For example, the distance between Sydney and Canberra is 237 kilometres by air. It is quite convenient for may travellers to use the road network rather than travelling to an airport at either end of the journey and queuing for a flight. The average distance of these routes is 891 kilometres so the weighting factor is a simple ratio of actual to average distance.

In comparison with actual data from the Department of Transport and Communications, the gravity model tends to overstate traffic between large centres and centres which are in relatively close proximity. This would tend to suggest that there are a range of other factors driving the base level demand for air services which require further investigation. However, this is beyond the scope of this paper.

The implication of the model, however, is that airlines will tend to concentrate their strategic efforts by running services through high volume airports in order to gain economies in aircraft utilisation and operation. Pioneering services to relatively thin markets is a more risky strategy and one which is far more vulnerable to competitive responses from other airlines. 


\section{Chapter 6 Conclusions}

This paper has examined the main business strategies available to airline managers from the perspective of two key organisational goals: profitability and market share. These goals are crucial to the assessment of the operations of an airline and are frequently used as measures of the performance of the company. There are several main conclusions which can be drawn from the analysis above.

The organisational paradigm and the assessment of airlines' business situations are crucial in developing the broad strategic direction and operational strategies that airlines pursue. This was drawn out in Chapter 2 and highlighted in the focus on organisational goals and the impact of a comprehensive situation assessment. The discussion of the major elements of marketing highlight the impact of marketing on an airline business strategy and place some of the business tactics airlines pursue which are discussed later in the paper within a marketing context

The business strategies identified why, from a theoretical perspective, the traditional management paradigm of profit-market share was not a feasible overall strategy for an airline however there might be some applicability of that paradigm in the management of a portfolio of routes. A range of other factors were broadly discussed and airline specific industry factors were introduced within these generic frameworks in Chapter 3.

The explicit focus on market share and profitability were integrated in a value chain concept rather than being examined as a functional relationship. Whilst profitability is not a function of market share, both factors were introduced into a common value chain framework in Chapter 4 allowing airline managers to understand that the nature of the profitability-market share relationship was not a simplistic one but one which required careful consideration as part of a broader corporate strategy. The 
other element which was discussed in this chapter was the relationship between the supply side value chain developed by Porter and a demand side analysis of customer value.

A counterfactual analysis which assumed an explicit relationship some of the fundamental pricing-service frequency responses and generated particular profitability-market share outcomes was assessed in an empirical analysis in Chapter 5. This revealed that the profitability-market share relationship at best is a weak one, given the large number of assumptions required to generate a stable model. Many of the factors affecting the industry which are assumed to be constant are in fact in a state of constant change.

The simplistic profitability-market share relationship is not a feasible technique for running a major airline given the wide range of factors impacting on airline operations. This paper has tied strategic management approaches into the regular operation of airline services, providing further evidence for airline managers of the relationship between key corporate decisions and bottom line results. 


\section{Bibliography}

Air Transport Action Group (1991) The Economics Benefits of Air Transport, Geneva, Switzerland

Asian Development Bank (1993) Asian Development Outlook, Oxford University Press, Hong Kong

Boeing Commercial Airplane Group (1993) Current Market Outlook: World Market Demand and Airplane Supply Requirements, Seattle, Washington

Bureau of Tourism Research (1992) International Visitor Survey, Canberra and previous issues

Bureau of Transport and Communication Economics (1993) The Progress of Aviation Reform, Report 81, Australian Government Publishing Service, Canberra (1992a) Quality of Service in Australian Passenger Aviation, Report 80, Australian Government Publishing Service, Canberra (1991a) A New Era in Australian Aviation - Conference Papers, Australian Government Publishing Service, Canberra (1991b) Deregulation of Domestic Aviation - The First Year, Report 73, Australian Government Publishing Service, Canberra (1990) Costs and Benefits of A Single Australasian Aviation Market, Australian Government Publishing Service, Canberra (1988) Trends and Prospects for Australian International Air Transport, Occasional Paper 88, Australian Government Publishing Service, Canberra

Cain, B. and Harbison, P. (1993) 'Deregulation of Domestic Aviation in USA, Canada, and Australia: A Comparison of Approach, Impacts and 
Implications' in Papers of the Australasian Transport Research Forum, Vol.18, Part 1, Graduate School of Management, University of Queensland, pp143-61

Caves, D., Christensen, L. and Tretheway, M. (1984) 'Economies of density versus economies of scale: Why trunk and local service airline costs differ', Rand Journal of Economics, Winter, pp471-89

Chu Te, G. (1993) 'Airline Deregulation and Domestic Tourism' in Papers of the Australasian Transport Research Forum, Vol.18, Part 1, Graduate School of Management, University of Queensland, pp259-75

Department of Industry, Technology and Commerce and the Australian Coalition of Service Industries (1992) International Competitiveness of Australian Service Industries, Report 11, Service Industries Research Program, Canberra

Department of Transport and Communications (1992) Air Transport Statistics Australian Air Distances, Fourth Edition, Canberra (1992) Annual Report: 1991-92, Canberra (1993a) Air Transport Statistics - Domestic Airlines - March Quarter 1993, Provisional Data, Canberra (1993b) Air Transport Statistics - Monthly Provisional Statistics of International Scheduled Air Transport, April 1993, Canberra and previous issues (1993c) Domestic Airline Activity - Weekly Status Report, Issue 1 for 199394 and previous weekly issues

Department of Treasury (1993) Economic Round-Up, Winter 1993, Australian Government Publishing Service, Canberra

Doganis, R. (1966) 'Traffic Forecasting and the "Gravity Model"' in Flight International, 29 September, pp547-9 
Federal Airports Corporation (1992) Annual Report: 1991-92, Melbourne

Forsyth, P. (1993) 'Corporatisation, Privatisation, and the Regulation of Australia's Airports' in Papers of the Australasian Transport Research Forum, Vol.18, Part 1, Graduate School of Management, University of Queensland, pp183-201

Gillen, D., Oum, T. and Tretheway, M. (1985) Airline cost performance: Implications for public and industry policies, Centre for Transportation Studies, University of British Columbia, Vancouver, Canada

Grieve Smith, J. (1985) Business strategy - An Introduction, Basil Blackwell and The Economist Publications, Oxford and London

Hamermesh, R.G. (1986) Making Strategy Work - How Senior Managers Produce Results, John Wiley and Sons, New York

Hardy, L. (1987) Successful business strategy: how to win in the market-place, Kogan Page, London

International Air Transport Association (1992) Asia/Pacific Air Traffic - Growth and Constraints, Geneva, Switzerland

Lancaster, K.J. (1966) 'A new approach to consumer theory' in Journal of Political Economy, April, pp132-57

Lancaster, K.J. (1971) Consumer Demand: A New Approach, Columbia University Press, New York

Lawrinsky, M. (1993) 'The Logic of International Airline Valuation' in Papers of the Australasian Transport Research Forum, Vol.18, Part 1, Graduate School of Management, University of Queensland, pp203-24

LeRoy Miller, Roger (1985) Intermediate Microeconomics: Theory, Issues, Applications, Second Edition, McGraw-Hill International Book Company, New York 
Levine, M. (1987) 'Airline competition in deregulated markets: theory, firm strategy and public policy', Yale Journal of Regulation, Vol 4, pp393-494

Mitchell, D. (1993) 'An Aggregate Model of International Airline traffic for Selected Asia Pacific Countries' in Papers of the Australasian Transport Research Forum, Vol.18, Part 2, Graduate School of Management, University of Queensland, pp1045-57

Mullins, L. (1989) Management and Organisational Behaviour, Pitman, London

Nyanthi, M.Z. (1993) 'Approaching an Airline Network Model of Competitive Strategy in International Aviation: A Conceptual Framework' in Papers of the Australasian Transport Research Forum, Vol.18, Part 2, Graduate School of Management, University of Queensland, pp1025-43

Organisation for Economic Cooperation and Development (1993) Main Economic Indicators, March 1993, Paris

Pearson, G.J. (1985) The Strategic Discount - Ways to an Entrepreneurial Strategy, John Wiley and Sons, New York

Peirson, G., Bird, R., Brown, R. and Howard, P. (1990) Business Finance, Fifth Edition, McGraw-Hill Book Company, Sydney

Peters, T.J. and Waterman, R.H. (1982) In Search of Excellence, Harper and Row

Petersen, H.C. and Lewis, W.C. (1990) Managerial Economics, Second Edition, Macmillan Publishing Company, New York

Porter, M.E. (1980), Competitive Strategy: Techniques for Analysing Industries \& Competitors, Free Press, New York

Porter, M.E. (1985) Competitive Advantage: Creating and Sustaining Superior Performance, Free Press, New York

Prideaux, B. (1993) 'Possible Effects of New Transport Technologies on the Tourism Industry in the 21st Century' in Papers of the Australasian Transport 
Research Forum, Vol.18, Part 1, Graduate School of Management, University of Queensland, pp245-57

Rimmer, P.J. (1993) 'Airline Passenger Networks and the Trans-pacific Spatial Economy' in Papers of the Australasian Transport Research Forum, Vol.18, Part 2, Graduate School of Management, University of Queensland, pp100723

Smith, D. and Street, J. (1992) 'Estimating the net welfare gains from Australian domestic aviation reforms in Papers of the Seventeenth Australasian Transport Research Forum, Canberra, pp709-728

Stephenson, F.J. and Fox, R.J. (1987) 'Corporate attitudes towards frequent-fliers programs', Transportation Journal, Vol.27, No.1, Fall 1987, pp10-22

Street, J., Spence, P. and Smith, D. (1993) 'Entry and Exit Conditions for Australian Aviation' in Papers of the Australasian Transport Research Forum, Vol.18, Part 1, Graduate School of Management, University of Queensland, pp163-81

Tirole, J (1990) The theory of industrial organisation, MIT Press, Cambridge, Massachusetts, USA

Tisdell, C.A. (1986) Microeconomics of Markets, John Wiley and Sons, Brisbane

Tretheway, M. and Oum, T.H. (1992) Airline economics: foundations for strategy and policy, Centre for Transportation Studies, University of British Columbia, Vancouver, Canada

Waud, R.N. and Hocking, A. (1992) Microeconomics, Second Australian Edition, Harper Educational Publishers, Artarmon, Australia

Woo, C.Y. and Cooper, A.C. (1983) "Evaluation of the Strategies and Performance of Low ROI Market Share Leaders", Strategic Management Journal, April-June 1983 